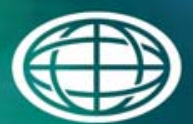

Savannah River

National Laboratory "m

OPERATED BY SAVANNAH RIVER NUCLEAR SOLUTIONS

\title{
2016 Alabama PV Soft Cost and Workforce Development
}

Elise B. Fox

Thomas B. Edwards

December 2016

SRNL-STI-2016-00717, Revision 0 


\section{DISCLAIMER}

This work was prepared under an agreement with and funded by the U.S. Government. Neither the U.S. Government or its employees, nor any of its contractors, subcontractors or their employees, makes any express or implied:

1. warranty or assumes any legal liability for the accuracy, completeness, or for the use or results of such use of any information, product, or process disclosed; or

2. representation that such use or results of such use would not infringe privately owned rights; or

3. endorsement or recommendation of any specifically identified commercial product, process, or service.

Any views and opinions of authors expressed in this work do not necessarily state or reflect those of the United States Government, or its contractors, or subcontractors.

\section{Printed in the United States of America \\ Prepared for U.S. Department of Energy}


Keywords: solar, soft cost, residential, commerical, PV, Alabama,

Retention: Permanent

\section{Alabama PV Soft Cost and Workforce Development}

Elise B. Fox

Thomas B. Edwards

December 2016

Prepared for the U.S. Department of Energy under contract number DE-AC09-08SR22470. 


\section{REVIEWS AND APPROVALS}

\section{AUTHORS:}

Elise B. Fox, Energy Materials

Date

Thomas B. Edwards, Engineering Process Development

Date

TECHNICAL REVIEW:

Holly L. Watson, Analytical Development

Date

APPROVAL:

Justin Halverson, Manager

Date

Energy Materials

Krissy Zeigler, Manager

Date

Materials Science \& Technology 


\section{ACKNOWLEDGEMENTS}

This work would not be possible without the support of our SuNLaMP team and various individuals and installers in Alabama. In particular, we would like to thank Daniel Tait of Energy Alabama for ensuring that the survey was distributed to the respondents, reviewing this document, and serving as a continual sounding board throughout the course of this project. Without them, this work would never have come to fruition. We are extremely thankful for their generous, continuous support and advice.

This work is funded by the Department of Energy Solar Energy Technology Program's SunShot National Laboratory Multiyear Partnership (SuNLaMP). The authors wish to thank the SunShot Balance of Systems team for their support of this work, in particular, Shubha Jaishankar for project management and review of this document.

The authors also wish to thank Holly Watson, SRNS, for statistical review of the results provided within this document. 


\section{EXECUTIVE SUMMARY}

The Southeastern US has the largest potential for growth in the solar industry. However, currently they languish behind the rest of the US. There are several bright spots including the large number of utility scale installations in North Carolina and the recent successes in South Carolina under Act 236. In order to better understand the impacts of state legislation on the growth of the solar industry in the SE US, the Savannah River National Laboratory has undertaken a study to look at the growth in each state in order to develop recommendations to help reduce the cost of solar and to spur the industry. This is the second report in the series. The first focused on developing cost metrics for South Carolina under Act 236. This report focuses on Alabama, the $49^{\text {th }}$ ranked state for solar business, which has very similar population and median income to South Carolina.

For this survey, the ten known in-state installers were contacted. Responses were received from seven, representing $70 \%$ of the installers, a majority of which provide both residential and commercial installations. Interestingly, none of the respondents serve the utility scale sector. Overall, costs for Alabama are on track with the rest of the country with a reported average cost of $\$ 3.29 / \mathrm{W}$-DC for residential systems and $\$ 2.44 / \mathrm{W}$-DC for commercial systems. $60 \%$ of this cost is attributed to hardware only. Of the remaining costs, installation contributed to the largest percentage of soft costs followed by overhead, marketing and sales, and permitting, respectively. This also closely mirrors results seen in South Carolina.

Job growth in the industry is expected to proceed well. An expected 34-42 additional full time equivalent jobs were expected to be added in Alabama within the six month window following the survey period. During the three years following the survey, this number was expected to double with 89-97 additional jobs being added to the market. In both cases, a vast majority of these jobs were for installation professionals and electricians.

| Despite the cost of solar, the industry continues to struggle in Alabama, largely due to the absence of any statewide net metering legislation. By current best estimates, there are over 60 residential installations statewide; however, this number is difficult to track due to the lack of a State authority keeping a consolidated list of grid connected distributed power systems. In South Carolina, the Energy Office tracks and reports grid connected distributed power systems by all Cooperatives and utilities. In Alabama, the Energy Office does not fulfill this role and data must be collected directly from each utility and cooperative, which makes collection and analysis difficult. Having a central state agency track this information would be extremely useful towards developing state policy recommendations, particularly if net metering were enabled within the state. 


\section{TABLE OF CONTENTS}

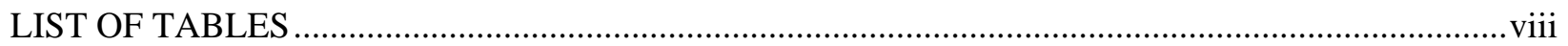

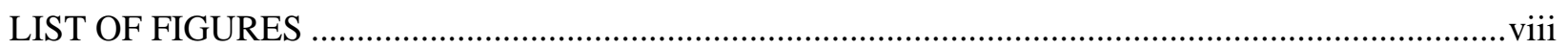

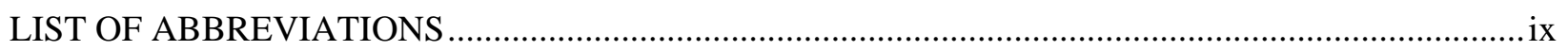

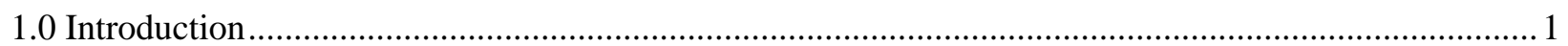

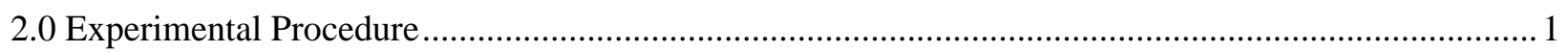

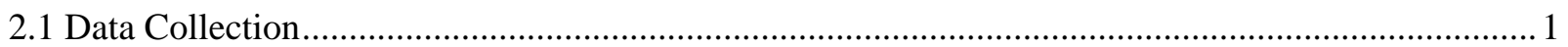

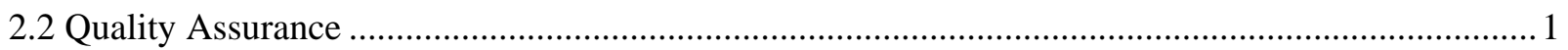

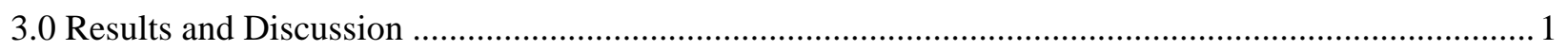

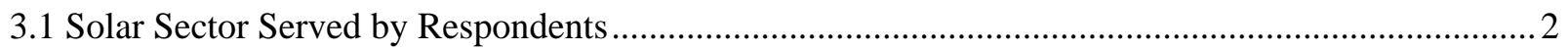

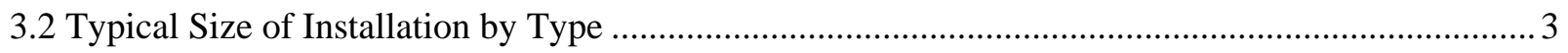

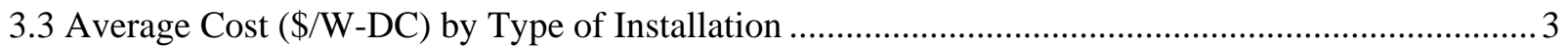

3.4 Average Hard and Soft Cost (\$/W-DC) by Type of Installation .................................................... 5

3.5 Average Soft Cost (\$/W-DC) by Category by Type of Installation ................................................ 6

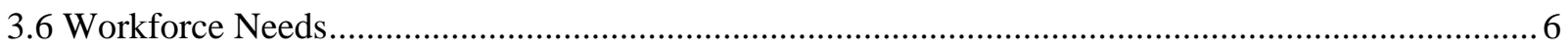

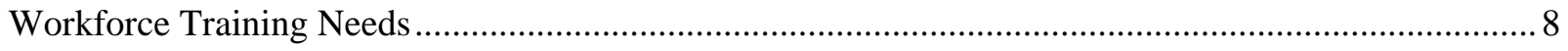

3.7 Biggest Opportunity to Reduce Soft Costs.................................................................................... 10

3.8 Business service territories in Alabama and in the Southeastern US ............................................ 10

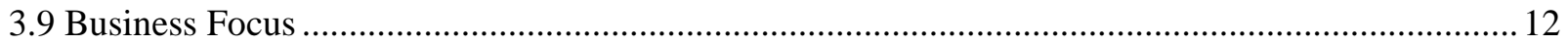

3.10 Installation Experience: Overall Career and within AL ........................................................... 13

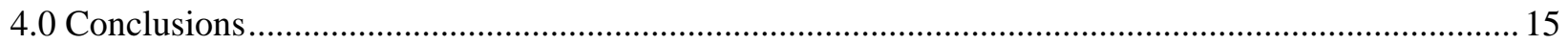

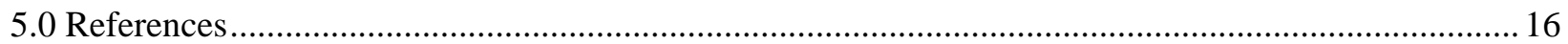

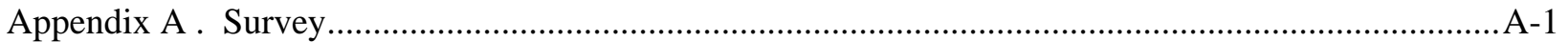

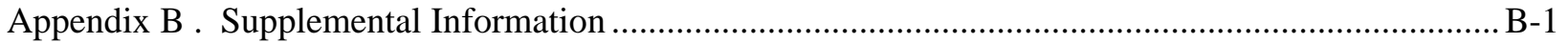




\section{LIST OF TABLES}

Table 3-2. Total Cost Separated into Hardware and Soft Costs. ........................................................... 6

Table 3-3. Total reported short and long-term job needs by job type................................................... 7

Table 3-4. Average short and long-term job needs by job type, per employer......................................... 8

Table 3-5. Population and average median income by region........................................................... 12

\section{LIST OF FIGURES}

Figure 3-1. Solar PV Segments Served by Respondents. Those that serve the residential sector are

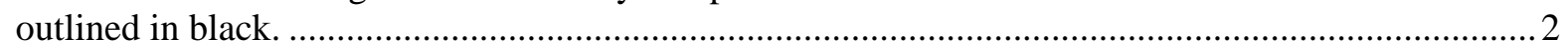

Figure 3-2. Average PV Installation Size (kW-DC), by sector served. …................................................ 3

Figure 3-3. Cost of PV Installations in \$/W-DC, by Respondent. ........................................................ 4

Figure 3-4. Variability Plot for Total Cost Data in \$/W-DC. ................................................................... 5

Figure 3-5. Reported Percent of Total Cost Attributed to Hardware Only, by Respondent. ...................... 5

Figure 3-6. Breakdown analysis of total costs into hard and soft, per sector........................................... 6

Figure 3-7. Breakdown analysis of soft costs in four categories, per sector............................................ 6

Figure 3-8. Expected short and long term job needs as reported by job type for both residential and commercial needs, per employer. ............................................................................................... 7

Figure 3-9. Service territories in the Southeastern US of companies surveyed....................................... 11

Figure 3-10. Alabama business service territories of respondents......................................................... 12

Figure 3-11. Business Focus Areas by Industry Segment Served. ...................................................... 13

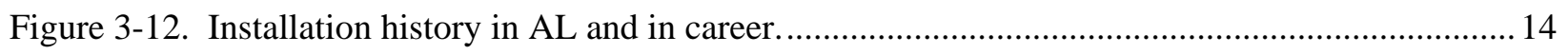

Figure 3-13. Total AL installed based on states served. ........................................................................ 14 


\section{LIST OF ABBREVIATIONS}

$\begin{array}{ll}\text { AC } & \text { Alternating current } \\ \text { AL } & \text { Alabama } \\ \text { DC } & \text { direct current } \\ \text { IOU } & \text { Investor Owned Utility } \\ \text { kW } & \text { kilowatt } \\ \text { MW } & \text { megawatt } \\ \text { PV } & \text { photovoltaic } \\ \text { SE } & \text { Southeast } \\ \text { SRNL } & \text { Savannah River National Laboratory } \\ \text { SRNS } & \text { Savannah River Nuclear Solutions } \\ \text { SC } & \text { South Carolina } \\ \text { SuNLaMP } & \text { SunShot National Laboratory Multiyear Partnership }\end{array}$




\subsection{Introduction}

Solar energy has had significant growth over the past five years in both the residential and utility sectors. Early 2016 was celebrated as the time of the one millionth distributed solar installation and a 54\% decrease in cost for distributed (photovoltaic) PV systems [1]. This equates to a reduction from approximately $\$ 7 / \mathrm{W}$ in 2010 to a $\$ 4 / \mathrm{W}$ in 2015 for residential consumers. However, this growth has not been uniform across the US. California and the Southwestern US continue to dominate in new utility and distributed installations and NV Energy reported a record low price of $4 \$ / \mathrm{kWh}$ at a new $100 \mathrm{MW}$ facility in Boulder City [2]. Despite having very good solar irradiance, the Southeastern US has lagged behind in solar penetration and now represents the greatest area for potential growth and future markets.

Three of the four states in the US that do not have legislation enabling net metering reside in the Southeast (SE): Tennessee, Alabama, and Mississippi [3]. South Dakota is the fourth state. Remarkably, the SE is also the home of some of the highest profile legislation enabling the expansion of solar in recent years. In the summer of 2014, South Carolina Governor Nikki Haley signed into law Act 236 which requires the state's investor-owned utilities (IOU) to have $2 \%$ of their peak power production generated by harnessing energy from the sun at the end of 2021. Growth of the solar industry in the state is being carefully tracked to help determine the effects this legislation has ${ }_{2}$ not only on cost, but also access [4]. Alabama and South Carolina have very similar populations and median incomes. Several key differences include that South Carolina has Act 236, net metering legislation, and a state tax credit for residential PV systems, while Alabama does not. In order to help track the growth of the solar industry in the SE and make recommendations to further reduce the cost of solar power for its consumers, it is important to understand the market and what policies best enable it. This makes the study of states with relative low solar penetration just as important as states with high penetration.

\subsection{Experimental Procedure}

\subsection{Data Collection}

The results of the seven Alabama companies captured in this survey equate to responses from $70 \%$ of the known in-state installation companies. A recent survey by The Solar Foundation ${ }^{\mathrm{TM}}, f$ reported that there are 34 solar companies operating in Alabama (AL) [5], which is calculated from the Solar Energy Industries Association's National Solar Database [6]. However, this number represents all sectors of the industry, including manufacturing and research and development. Working with Energy Alabama, the ten known in-state installation companies were contacted to complete this survey. Responses were received from seven, which indicates a 70\% response rate. The analyses presented in this report were conducted using JMP Pro Version 11.2.1 [7].

\subsection{Quality Assurance}

Requirements for performing reviews of technical reports and the extent of review are established in SRNL Manual E7 2.60. SRNL documents the extent and type of review using the SRNL Technical Report Design Checklist contained in WSRC-IM-2002-00011, Rev. 2.

\subsection{Results and Discussion}

The fifteen-question survey was broken down into three parts focusing on: 1) establishing current costs of solar, 2) determining additional workforce needs and suggested training for those positions, and 3) determining the focus and experience of the respondents. Detailed analysis of the survey is presented and

\footnotetext{
${ }^{f}$ The Solar Foundation ${ }^{\mathrm{TM}}$ is an independent 501(c) (3) nonprofit with a stated mission: "to increase understanding of solar energy through strategic research and education that transform markets.”
} 
discussed below. Where possible, data are broken down by individual sectors: residential, commercial, and utility.

\section{1 $\underline{\text { Solar Sector Served by Respondents }}$}

Respondents were asked to indicate all segments of the solar business sector that they serve. The results are presented in graphical form in Figure 3-1, with the total percent and number of installers in parenthesis. Over $71 \%$ of survey respondents primarily serve both the residential and commercial sectors. One installer serves only residential customers, while a second serves only commercial customers. Interestingly, no respondents serve the utility sector. This suggests that local installers, given their limited experience in the utility sector of solar, may have little involvement in the recently proposed $500 \mathrm{MW}$ of renewable generation proposed by Alabama Power [8] or the 80 MW TVA facility at River Bend [9].

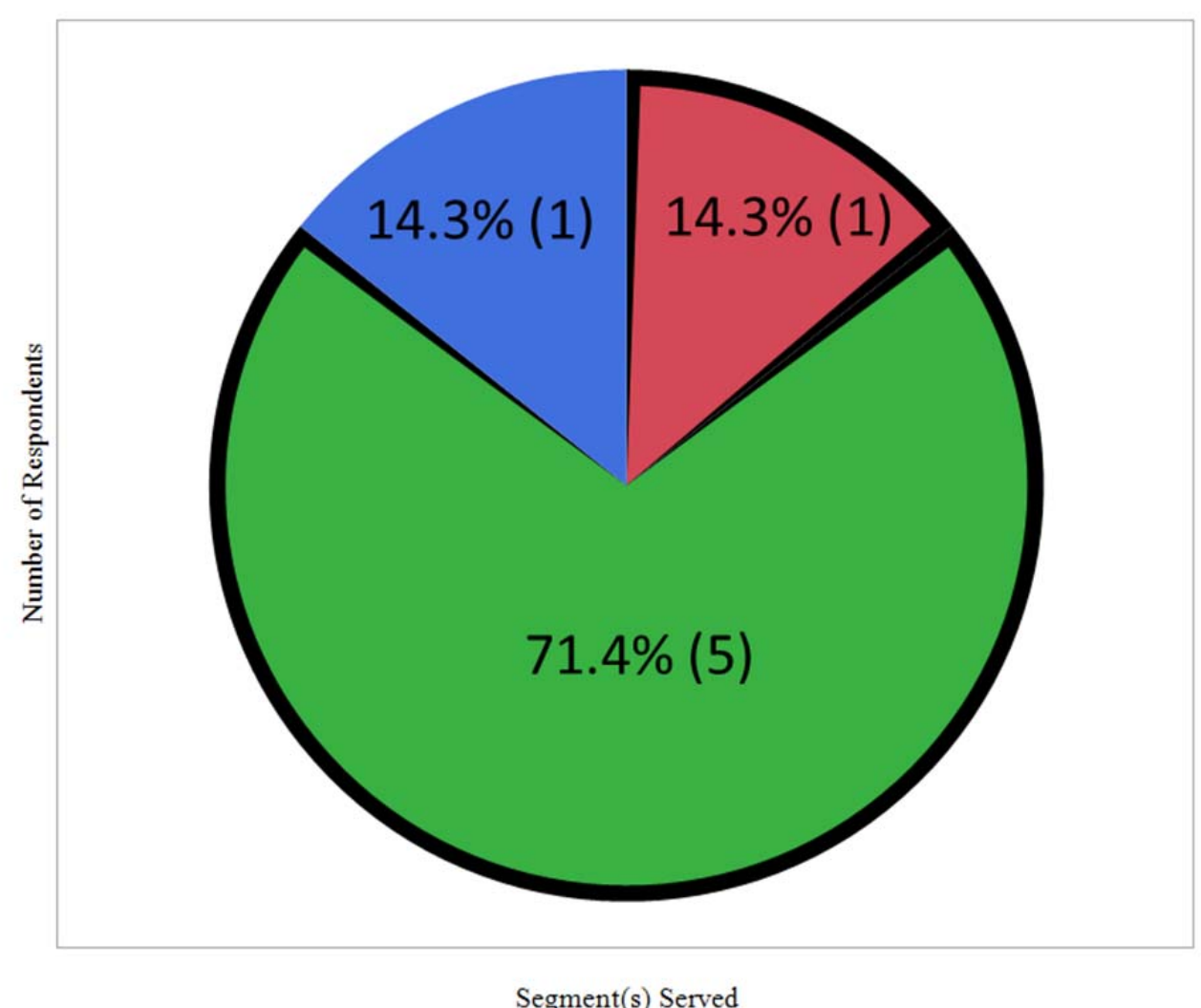

Segment(s) Served Residential Residential/Commercial Commercial

Figure 3-1. Solar PV Segments Served by Respondents. Those that serve the residential sector are outlined in black. 


\subsection{Typical Size of Installation by Type}

The survey respondents were asked about the typical size of their installations (residential and commercial) in Alabama. The installation size was provided in kilowatts of direct current (kW-DC), and in some cases, a range of sizes was provided by a respondent. Figure 3-2 provides a graphical display (including box plots ${ }^{1}$ ) of the installation sizes (low-end and high-end estimates) for both residential and commercial installations. Excluding the one potential outlier for the high-end estimates of the residential installations in Figure 3-2, the remaining reported residential installations in AL were all less than or equal to $8 \mathrm{~kW}$-DC with an average size of $\sim 6 \mathrm{~kW}$-DC. The average size of the reported commercial installation in AL was 47 to $56 \mathrm{~kW}$-DC. The residential system size is slightly lower than the average of $9.45 \mathrm{~kW}$-DC reported for SC residential consumers in 2015, while the average commercial installation in SC was much larger at $168 \mathrm{~kW}-\mathrm{DC}^{2}$.

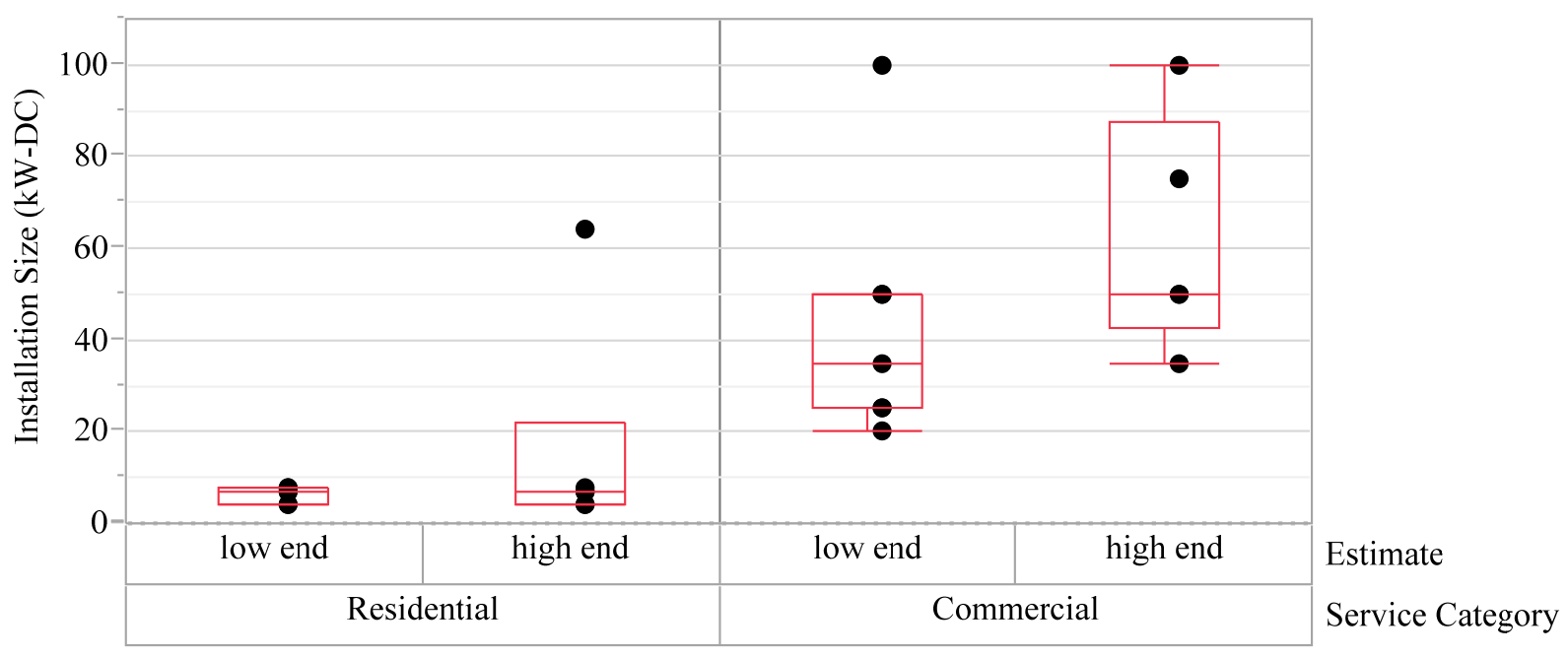

Figure 3-2. Average PV Installation Size (kW-DC), by sector served.

\subsection{Average Cost (\$/W-DC) by Type of Installation}

Respondents were asked to provide information on the total cost in dollars per watt of direct current (\$/W-DC) by installation type. These data in \$/W-DC for the total cost by solar segment served are plotted in Figure 3-3 and Figure 3-4. Residential installs were found to average \$3.29/W-DC with a range of $\$ 2.60-\$ 5.00 / \mathrm{W}-\mathrm{DC}$. This is lower than the reported cost of $\$ 4.30 / \mathrm{W}$ for residential-system installs by year-end 2014 reported by Barbose, et al. [10], but within the recently reported range by Green Tech Media [11]. This is also lower than the 2015 cost for SC, but with a wider range between responses [4]. Commercial systems in AL had a reported average cost of $\$ 2.44 / \mathrm{W}$ with a range between $\$ 2.20-$ $\$ 2.85 / \mathrm{W}$. This corresponds well with the $\$ 2.25$ - \$3.50 range reported by SEPA [12] and was lower than the 2015 SC reported high and low average range of $\$ 2.65-\$ 2.70 / \mathrm{W}$ with a range of responses between $\$ 1.85$ - \$3.50/W [4]. This suggests that in Alabama the commercial sector is more competitive than the residential sector and that potential commercial customers are more likely to have a more knowledge on

\footnotetext{
${ }^{1}$ A box plot is a descriptive display used for continuous data. The lower edge of the box is the $25^{\text {th }}$ percentile, the upper edge the $75^{\text {th }}$ percentile, and the horizontal line within the box the $50^{\text {th }}$ percentile. Any points that fall beyond the lines extended from the box (i.e., points not connected to the box) of the box plot may be considered as potential outliers for the data set.

${ }^{2}$ Calculated from the average high and average low values reported in SC for 2015.
} 
photovoltaics options and on what to expect during an installation than potential residential customers in that state.

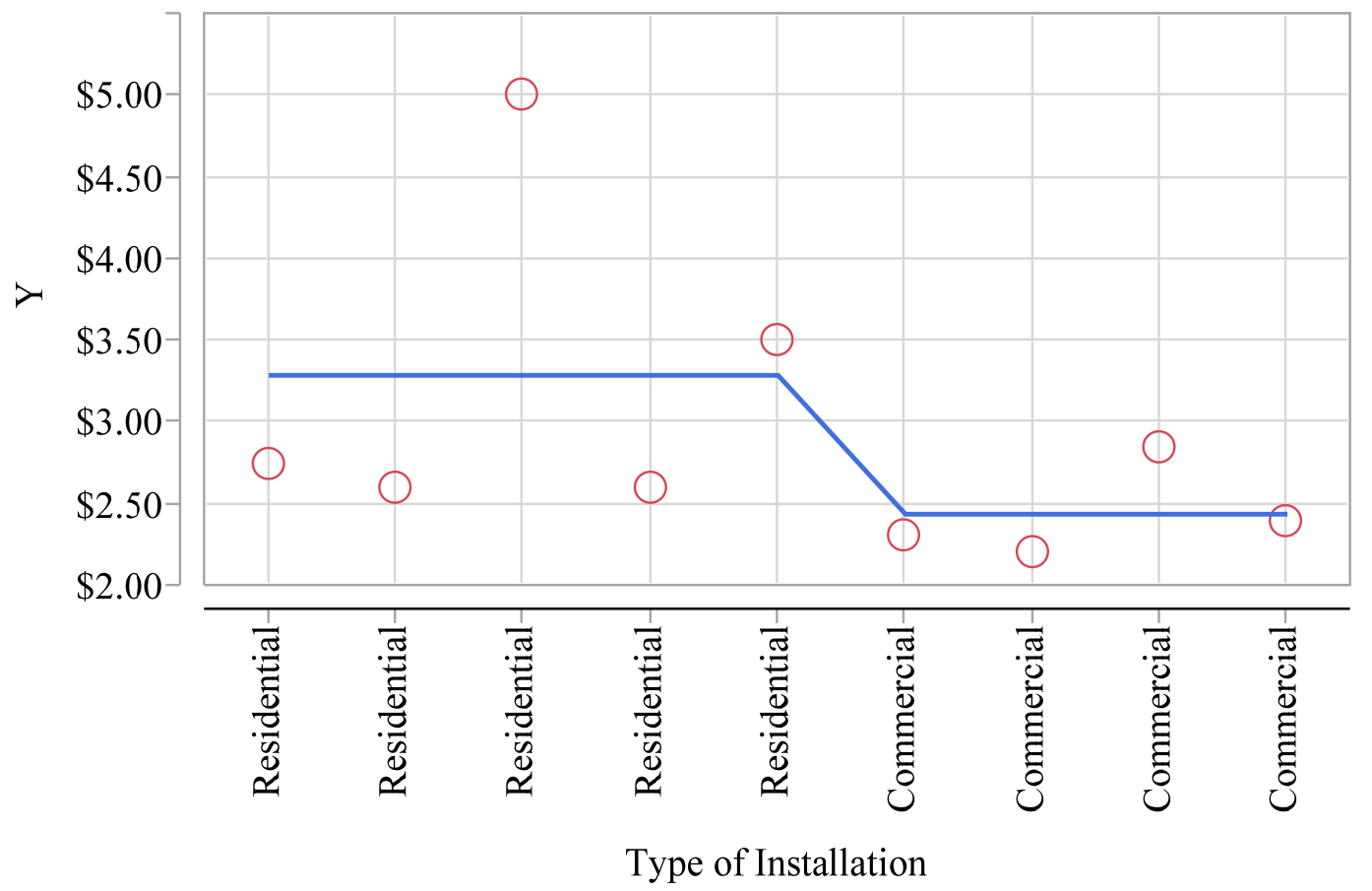

Figure 3-3. Cost of PV Installations in \$/W-DC, by Respondent.

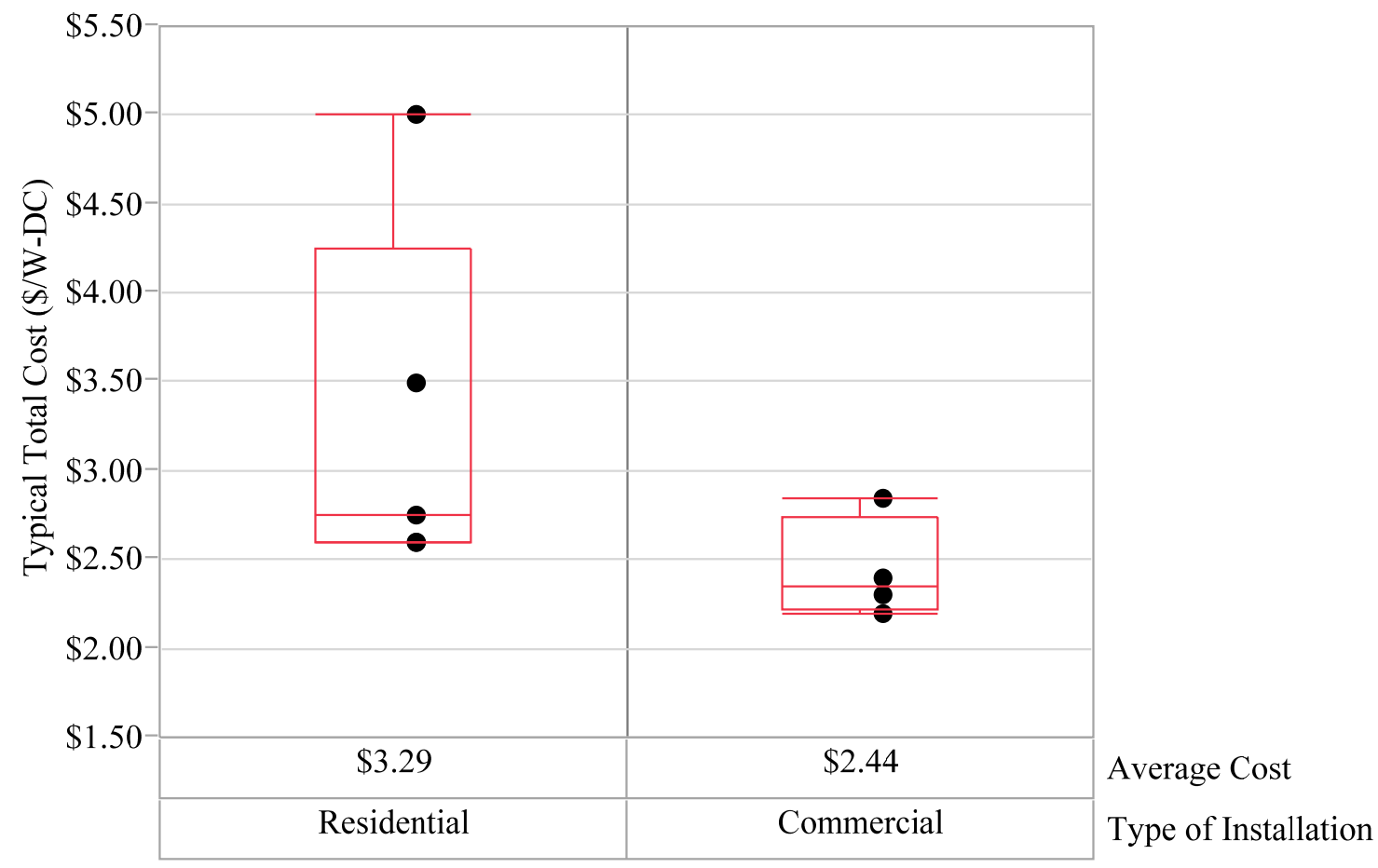


Figure 3-4. Variability Plot for Total Cost Data in \$/W-DC.

\subsection{Average Hard and Soft Cost (\$/W-DC) by Type of Installation}

Respondents were asked to provide the percent of the total cost attributable to hardware by installation type. The resulting estimated costs of hardware as a percentage of the total costs are provided in Figure 36 . Using these percentages, the total costs were further broken down into hardware and soft costs, and these values are provided in Figure 3-5. Hardware costs for AL residential installations average \$2.03/ WDC equaling on average $\sim 62 \%$ of the total costs, while commercial installations average $\$ 1.46 / \mathrm{W}$-DC equaling on average $\sim 60 \%$ of the total costs. This closely mirrors the percentages of hardware costs of $62 \%$ for residential and $62.5 \%$ for commercial reported for SC [4].

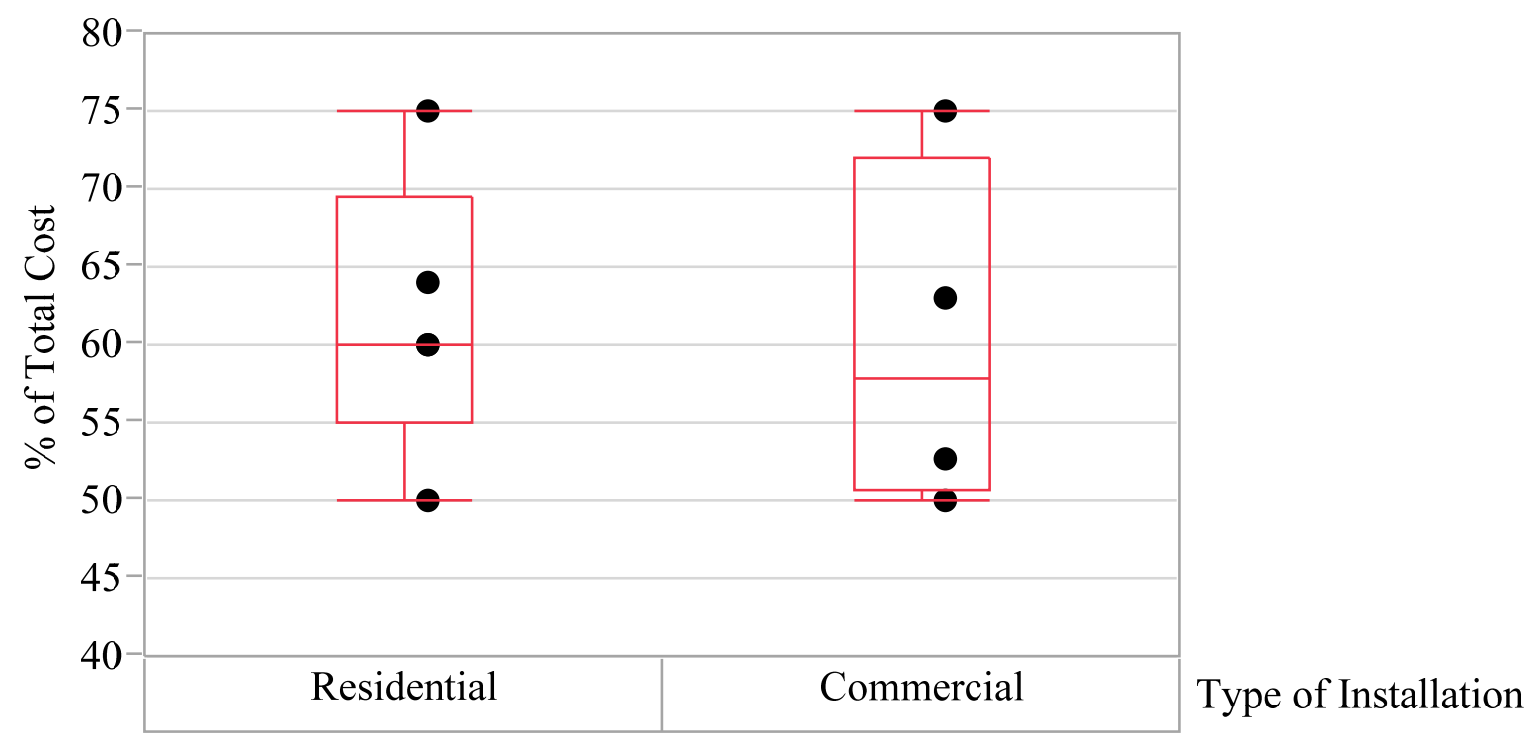

Figure 3-5. Reported Percent of Total Cost Attributed to Hardware Only, by Respondent.

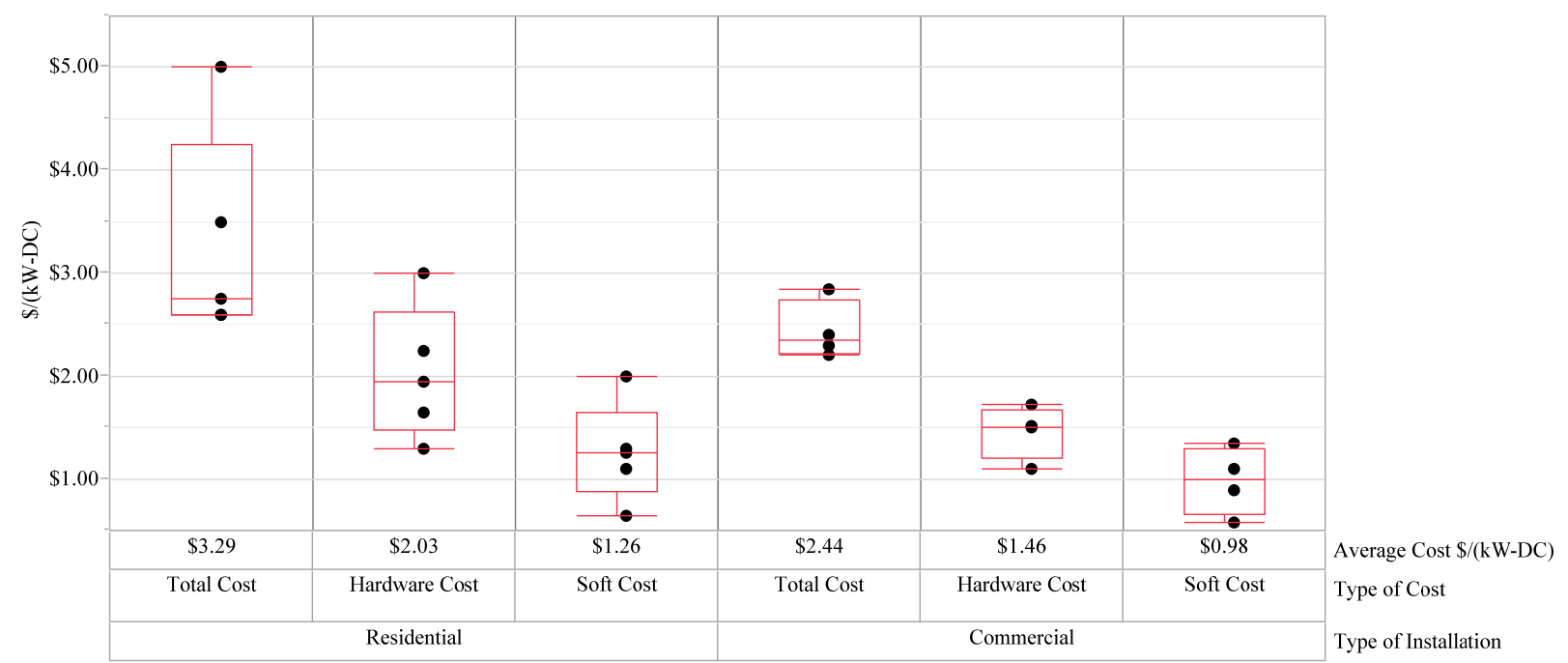


Figure 3-6. Breakdown analysis of total costs into hard and soft, per sector.

\subsection{Average Soft Cost (\$/W-DC) by Category by Type of Installation}

In order to better determine the largest contributor to soft costs, respondents were asked to provide information on the percent of the total cost attributable to several soft-cost categories by installation type. Four categories of soft costs were considered: 1) marketing, lead generation, and sales, 2) permitting and interconnection, including all fees and administrative labor costs, 3) installation, including design, engineering, and construction labor, and 4) profit, overhead, and taxes. The information on soft costs that was provided was applied to both residential and commercial total costs. The results are presented in Figure 3-7 and as average percentages and dollar values in Table 3-1. The largest soft cost is attributed to installation $>$ overhead $>$ marketing $>$ permitting. This is the same trend that was found in SC.

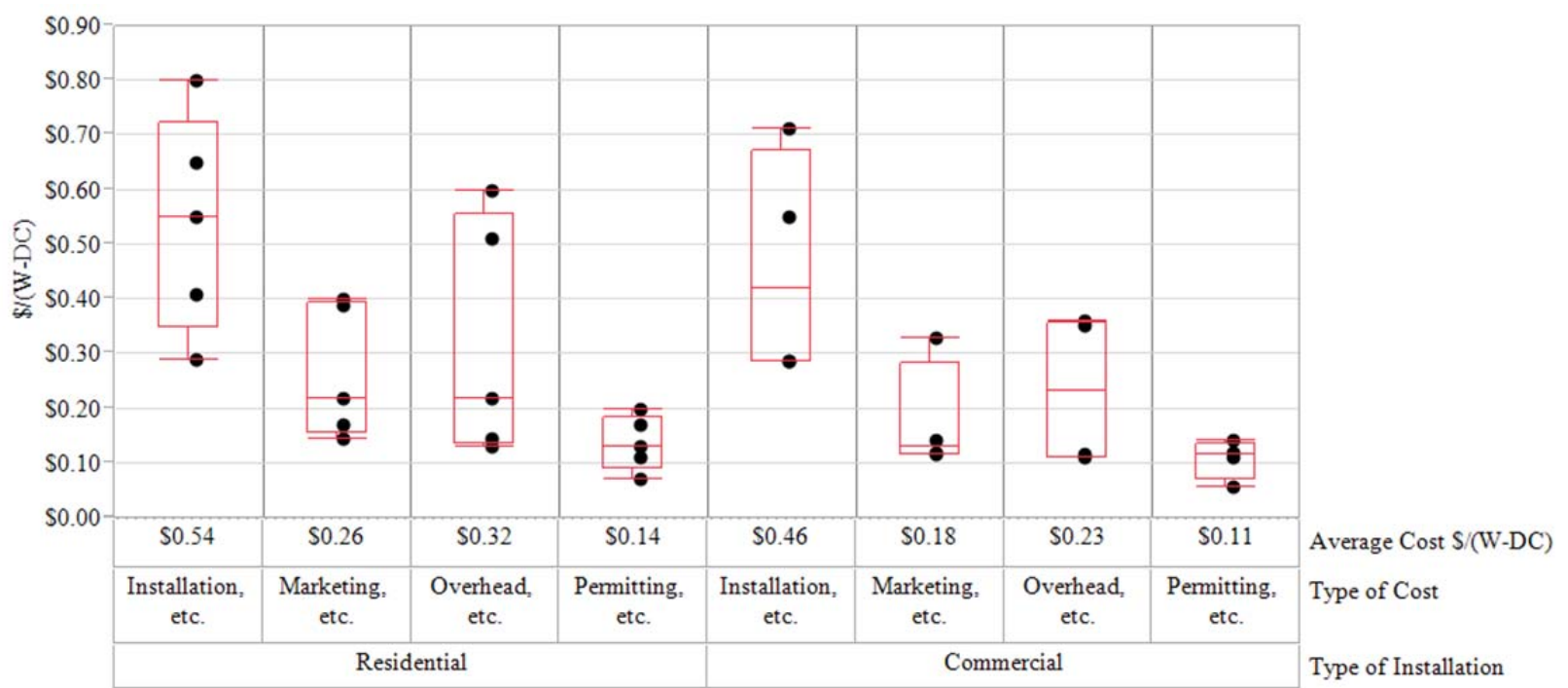

Figure 3-7. Breakdown analysis of soft costs in four categories, per sector.

Table 3-1. Total Cost Separated into Hardware and Soft Costs.

\begin{tabular}{|c|c|c|}
\hline Type of Cost & Residential Mean(\$/(W-DC)) & $\begin{array}{c}\text { Commercial Mean(\$/(W- } \\
\text { DC)) }\end{array}$ \\
\hline Total Cost & $\$ 3.29$ & $\$ 2.44$ \\
\hline Hardware Cost & $\$ 2.03(62 \%)$ & $\$ 1.46(60 \%)$ \\
\hline Installation, etc. & $\$ 0.54(16 \%)$ & $\$ 0.46(19 \%)$ \\
\hline Marketing, etc. & $\$ 0.26(8 \%)$ & $\$ 0.18(7 \%)$ \\
\hline Overhead, etc. & $\$ 0.32(10 \%)$ & $\$ 0.23(9 \%)$ \\
\hline Permitting, etc. & $\$ 0.14(4 \%)$ & $\$ 0.11(5 \%)$ \\
\hline
\end{tabular}

\subsection{Workforce Needs}

Survey recipients were asked to report their short (6 month) and long (3 year) term hiring needs in four job categories: engineering and design, electricians and installers, sales and marketing, and general business. The results are summarized in Table 3-2. AL is currently ranked $50^{\text {th }}$ in the nation for solar jobs 
per capita and $45^{\text {th }}$ for total solar jobs by The Solar Foundation [5]. However, job growth in 2016 is expected to exceed $20 \%$. This closely complements the reported six month job needs found in this survey, a low estimate of 34 and a high estimate of 42. A majority (over 70\%) of these needs were in the electrician and installer category.

Table 3-2. Total reported short and long-term job needs by job type.

\begin{tabular}{|c|c|c|c|c|}
\hline & \multicolumn{2}{|c|}{6 mos } & \multicolumn{2}{c|}{3 yrs } \\
\hline Type of Job & low & high & low & high \\
\hline design, engineering & $4(12 \%)$ & $4(10 \%)$ & $11(12 \%)$ & $11(11 \%)$ \\
\hline electrician \& installer & $24(71 \%)$ & $32(76 \%)$ & $52(58 \%)$ & $60(62 \%)$ \\
\hline gen. business & $2(6 \%)$ & $2(5 \%)$ & $14(16 \%)$ & $14(14 \%)$ \\
\hline sales \& marketing & $4(12 \%)$ & $4(10 \%)$ & $12(13 \%)$ & $12(12 \%)$ \\
\hline total & 34 & 42 & 89 & 97 \\
\hline
\end{tabular}

When comparing the average short and long term needs per business (see Figure 3-8), electricians and installers outweigh other business needs. This is also the only job category where it was typical for a respondent to provide a range of values, indicating that this position is more dependent on market conditions than the other job categories. On average, each respondent projects to hire $6-8$ new full-time employees in the six month period following this survey, which is slightly less than half of the open positions expected over the next three years (see Table 3-3).

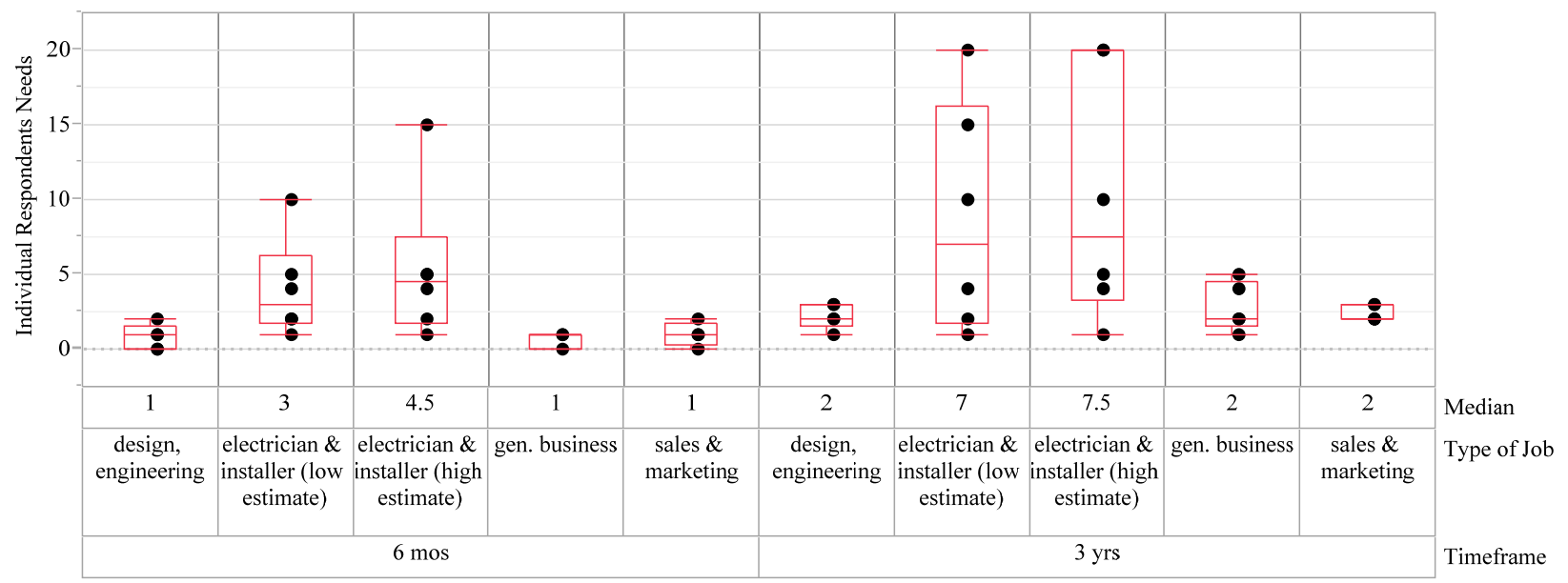

Figure 3-8. Expected short and long term job needs as reported by job type for both residential and commercial needs, per employer. 
Table 3-3. Average short and long-term job needs by job type, per employer.

\begin{tabular}{|c|c|c|c|c|}
\hline & \multicolumn{2}{|c|}{6 mos } & \multicolumn{2}{c|}{3 yrs } \\
\hline Type of Job & low & high & low & high \\
\hline design, engineering & 0.8 & 0.8 & 2.2 & 2.2 \\
\hline electrician \& installer & 4.0 & 5.3 & 8.7 & 10.0 \\
\hline gen. business & 0.7 & 0.7 & 2.8 & 2.8 \\
\hline sales \& marketing & 1.0 & 1.0 & 2.4 & 2.4 \\
\hline total & 6.5 & 7.8 & 16.1 & 17.4 \\
\hline
\end{tabular}

\section{Workforce Training Needs}

When rapid job growth is expected in a non-traditional workforce sector, a shortage of appropriately skilled workers can severely impact business growth. [13, 14] In order to better understand how businesses are meeting these requirements, survey respondents were asked if funding were available to support job training, what type of training they would recommend for four different job categories. The lack of available hands-on training can impede the growth of qualified PV installers. [14] The choices were NABCEP Entry Level, NABCEP Technical Sales, NABCEP PV Professional, and Other. Respondents were allowed to choose more than one option per job type. The following figure provides a plot showing the percent of the 7 respondents recommending each of the training levels within each of the position types. Technical Sales training for sales and marketing was recommended more than any other type of training in any job category. This could indicate a disconnection between immediate business needs and efforts by utilities to ensure a safe, quality installation on grid connected systems. PV Professional training was recommended most for crew chiefs. Entry Level training was recommended highest for installers. 


\section{Graphical Representation of Training Needs}

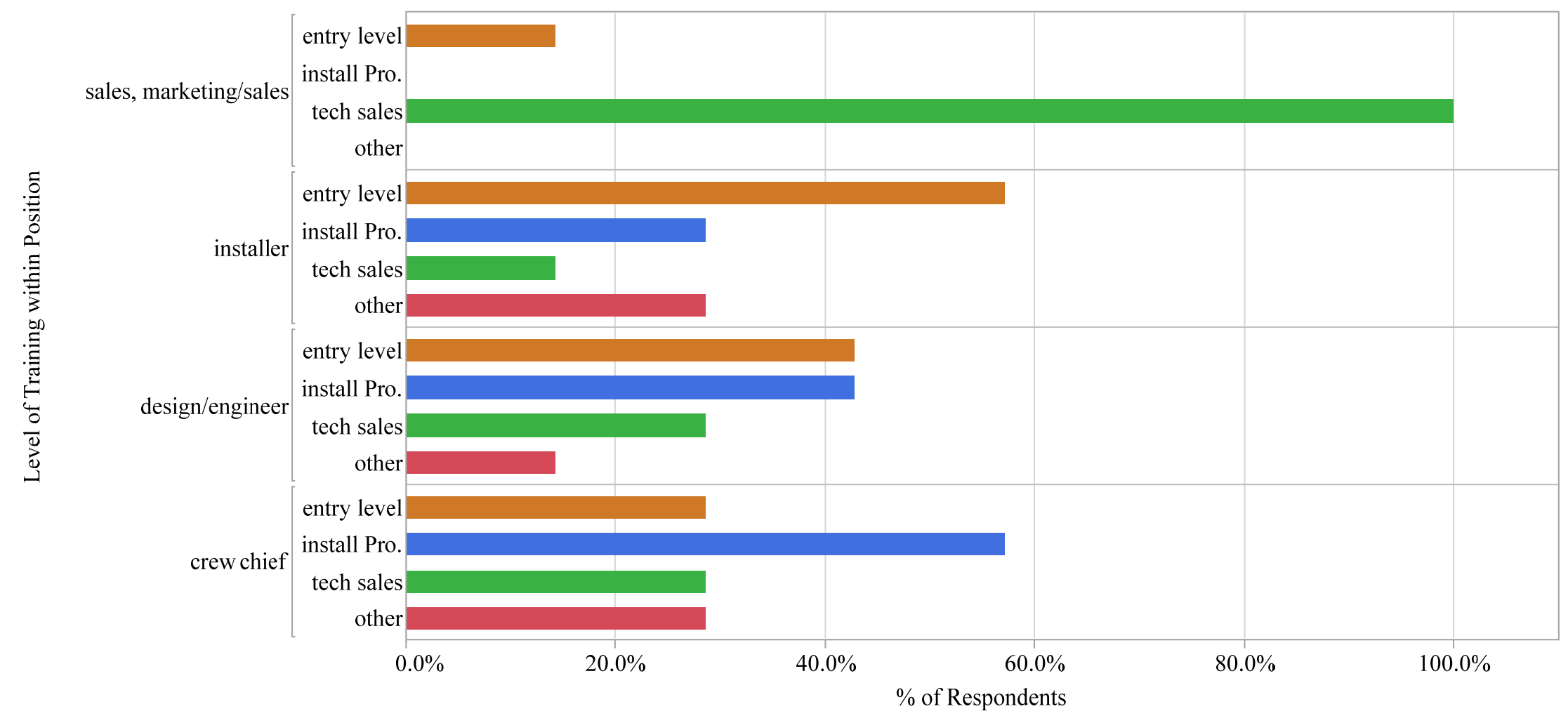

Level of Training $\square$ other $\square$ tech sales $\square$ install Pro. $\square$ entry level 


\subsection{Biggest Opportunity to Reduce Soft Costs}

Respondents were asked to describe what they viewed as the biggest opportunity to reduce non-hardware soft costs in Alabama. The responses, copied word for word and in a random order are:

1. More education and SunShot goals

2. If net metering is allowed it will reduce the sales cycle time and installation costs, significantly.

3. Streamline permitting process

4. AL Power charges homeowners who install PV \$5/kW/month which makes battery PV systems a requirement. Grid tied don't pay for themselves. The coops pay $3 \$ / \mathrm{kWh}$ and advise people not to do PV in their monthly magazines.

5. In AL the penalty associated to connecting to the grid is the biggest problem. Also, the removal of the penalty would be the biggest opportunity.

6. More solar friendly policies. Our biggest soft cost is site surveys, designs, and proposals for potential customers who ultimately pass because the economics are not there.

Clearly, one of the largest areas of concern for installers is the lack of net metering enabling legislation. As a result, homeowners and businesses with PV generation are only reimbursed at the avoided cost rate for excess generation and are often charged additional monthly fees to interconnect. For example, Alabama Power charges home owners $\$ 5 / \mathrm{kW} /$ month. If the average residential installation in AL is $6 \mathrm{~kW}$, the average month charge comes to $\$ 30 /$ month. This monthly charge likely negates any generation credits with the utility. Simply removing the monthly fee could help improve the rate of interconnection and adoption of distributed generation significantly.

\subsection{Business service territories in Alabama and in the Southeastern US}

The survey respondents were asked a number of questions to help better define the business climate and potential growth. Out of the seven respondents, four only work inside the state of Alabama. Three installers (43\% of respondents) also work in Tennessee. This is likely due to the Northern portion of the state residing in TVA service territory (see Figure B1 and B2 in Appendix B). Having gained experience working with TVA in Northern Alabama, the next natural progression is to expand business over the Tennessee/Alabama state line into additional TVA service territory. One installer, or $14 \%$ of respondents, works in Georgia.

When comparing the service territories of the survey companies in Figure 3-10 it is seen that the consumers in the Central regions have the largest selection of installers. The three major metropolitan areas of Huntsville, Birmingham, and Montgomery are located in the Northeast, Central-East, and MidEast regions, respectively. Interestingly, the largest number of installers located in the Central-west region which has the lowest population, lowest median income, and highest percent of persons living in poverty, see Table 3-4 (also see Table B1 in Appendix B). The Central-west region is home to the University of Alabama-Tuscaloosa, the main branch of the University. Tuscaloosa is also the fifth largest city in AL. $50 \%$ of the region's population lives within Tuscaloosa County, whose median income is $20-50 \%$ higher than the other counties within that region. 


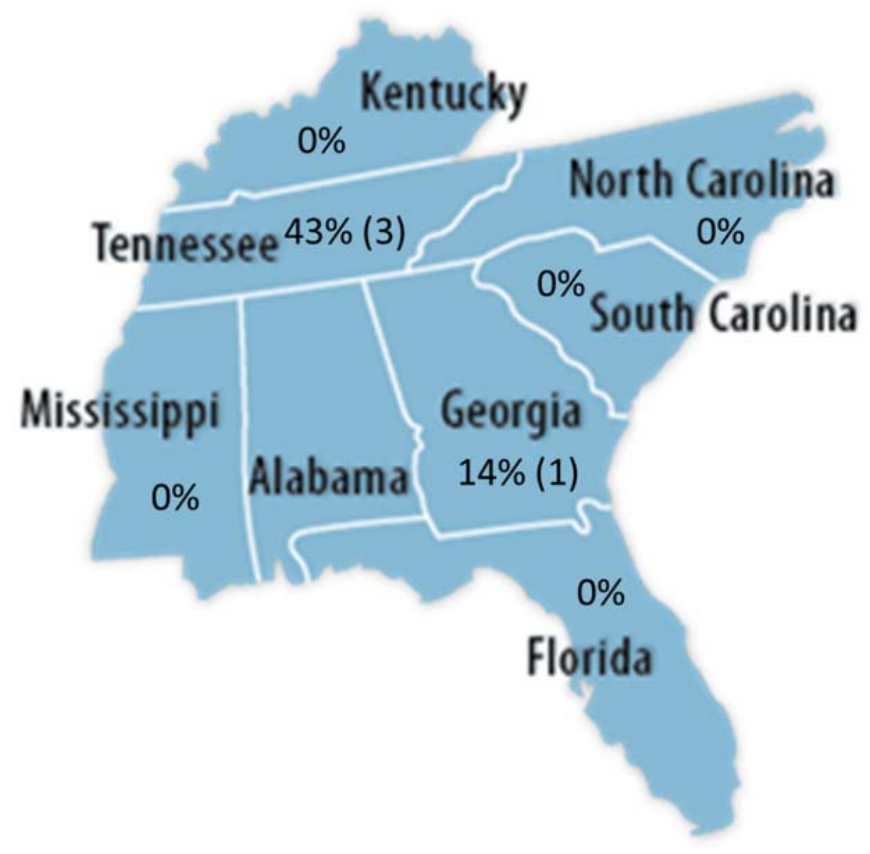

Figure 3-9. Service territories in the Southeastern US of companies surveyed. The number of Alabama installers is represented by percentage of total respondents and total number in parenthesis. 


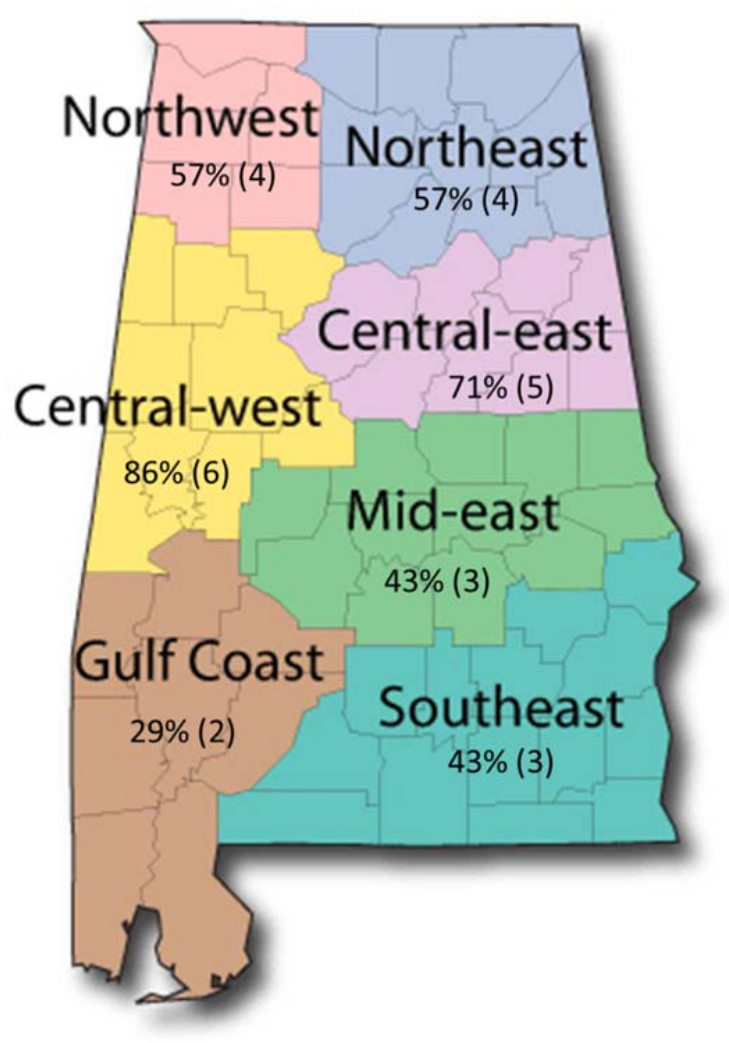

Figure 3-10. Alabama business service territories of respondents.

Table 3-4. Population and average median income by region.

\begin{tabular}{|ccccc|}
\hline \# of & & & & ${ }^{1}$ Average \\
Counties & Pepulation & $\begin{array}{c}{ }^{1} \text { Average } \\
\text { Income }\end{array}$ & $\begin{array}{c}\text { Percent } \\
\text { living in } \\
\text { poverty }\end{array}$ \\
\hline Northwest & 6 & 268,440 & $\$ 37,717.67$ & $19.2 \%$ \\
\hline Northeast & 10 & $1,022,585$ & $\$ 42,460.30$ & $18.3 \%$ \\
\hline Central-west & 10 & 385,304 & $\$ 32,155.00$ & $27.2 \%$ \\
\hline Central-east & 8 & $1,189,824$ & $\$ 43,985.75$ & $17.9 \%$ \\
\hline Mid-east & 11 & 711,068 & $\$ 38,466.82$ & $23.0 \%$ \\
\hline Gulf Coast & 8 & 708,297 & $\$ 36,465.38$ & $23.2 \%$ \\
\hline Southeast & 14 & 494,220 & $\$ 37,649.71$ & $22.9 \%$ \\
\hline State Total & 67 & $4,780,127$ & $\$ 43,511$ & $18.5 \%$ \\
\hline
\end{tabular}

1. Calculated from U.S Census Bureau Data, 2014; median income and \% in poverty were determined using a weighted (by population) average

\subsection{Business Focus}

Respondents were asked to identify their specific business focus in each sector. Figure 3-11 provides the results from the survey. The largest business focus for all responding companies was in installations. These companies will be most directly impacted by a shortage of qualified electricians, construction workers, and installers. Equipment supply and finance have not been given adequate attention, indicating that solar installers either purchase from the few companies in the state or through contracting out of state. 


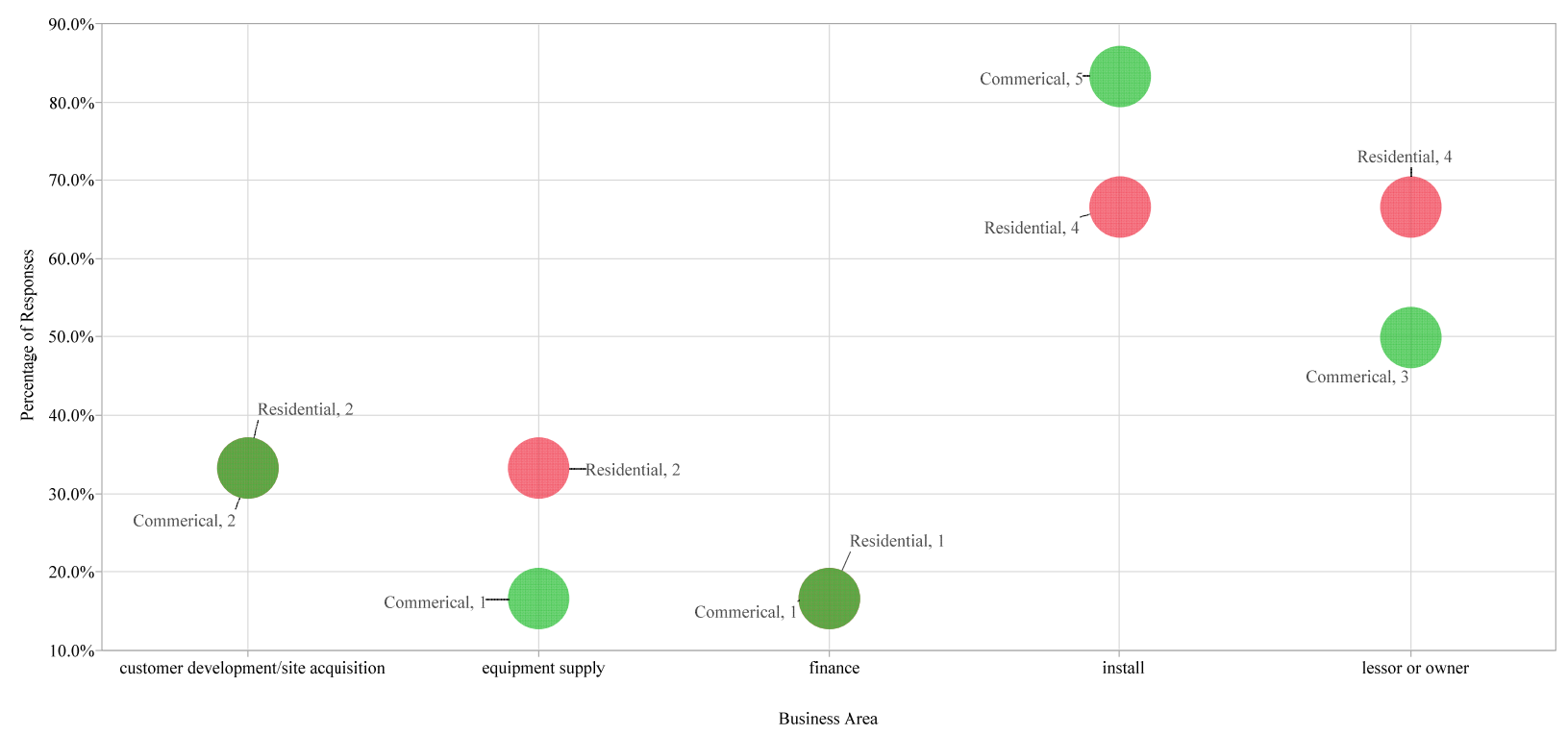

Figure 3-11. Business Focus Areas by Industry Segment Served.

\subsection{Installation Experience: Overall Career and within AL}

Respondents were asked to provide a measure of their experience in terms of their career total installed $\mathrm{kW}$ and their $\mathrm{Al}$ installed kW. Their installation histories are provided in Figure 3-12. Installations within the state mirror total career installs for all respondents. When this is further compared with how many states the installers serve, Figure 3-13, it is apparent that the solar industry in AL is young, but consistently growing. Companies that serve Alabama likely are locally started but then expand to neighboring states as they gain experience and understanding of the local utilities policies. 


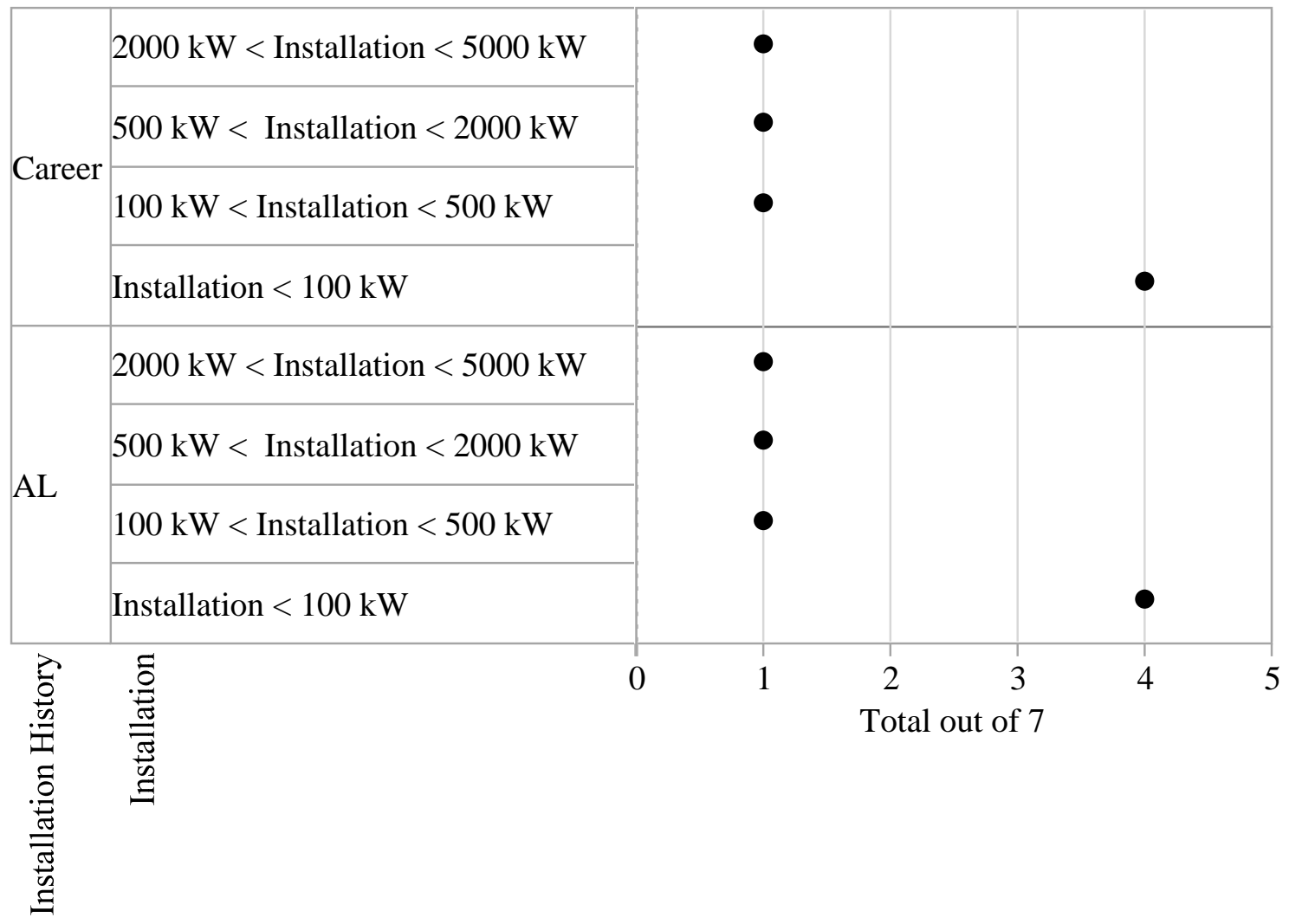

Figure 3-12. Installation history in AL and in career.

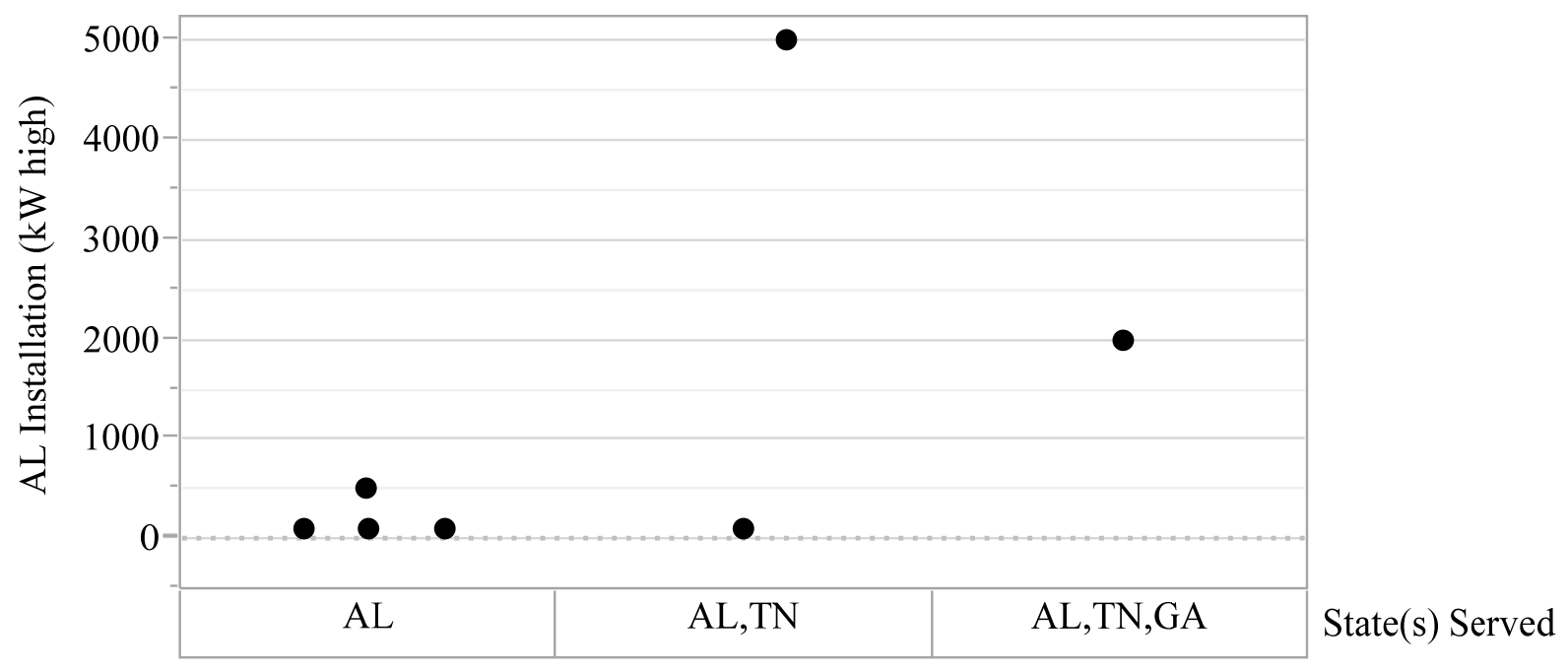

Figure 3-13. Total AL installed based on states served. 


\subsection{Conclusions}

The solar industry in AL is young, but price competitive with an average residential installation cost of $\$ 3.29 / \mathrm{W}-\mathrm{DC}$. $60 \%$ of the total cost is attributed to hardware only. Most of the installers interviewed for this report only install in AL, though a few have branched out to the neighboring states of AL and GA. None of the reporting installers serve the utility sector, which is indicative of the low penetration of solar in the state. Low growth of the industry within the state is likely due to the fact that AL is one of the few remaining states in the US without legislation enabling net metering. Without this, customers are currently reimbursed for excess production at the avoided cost rate, which is approximately $4 \mathbb{\$} / \mathrm{kWh}$. At the avoided cost rate and without state tax incentives, the distributed solar systems become cost prohibitive to a majority of residents. Despite the lack of net metering legislation, the AL solar industry continues to slowly grow and keep pace with costs in the rest of the SE. All reporting installers anticipate growth within their business as evident by increasing job needs. Several utility scale installations proposed by both TVA and Alabama Power will help to grow the visibility of the industry and its positive effects on the community. 


\subsection{References}

1. Donohoo-Vallet, P., et al., Revolution...Now: The Future Arrives for Five Clean Energy Technologies - 2016 Update. 2016, US Department of Energy.

2. NV Energy Seeks Approval for Renewable Energy Project and Earlier Retirement of Coal Generation, in PR Newswire. 2016.

3. Legislatures, N.C.o.S. Net Metering: Policy Overview and State Legislative Updates. 2016 10/20/16]; Available from: http://www.ncsl.org/research/energy/net-metering-policy-overviewand-state-legislative-updates.aspx.

4. Fox, E.B. and T.B. Edwards, 2015 South Carolina PV Soft Cost and Workforce Development Part 1: Inital Survey Results. DOE Technical Report, 2016. SRNL-STI-2016-00177.

5. $\quad$ TheSolarFoundation, State Solar Jobs Census Compendium 2015. 2016.

6. SEIA. National Solar Database. Available from: http://www.seia.org/researchresources/national-solar-database.

7. $\quad$ SAS Institute, I., JMP Pro Version 11.2.1. SAS Institute, Inc.: Cary, North Carolina.

8. Roselund, C., Alabama approves up to 500MW of renewable energy over the next six years, in $P V$ Magazine. 2016.

9. River Bend Solar Project. 10/20/16]; Available from: https://www.tva.gov/Environment/Environmental-Stewardship/Environmental-Reviews/RiverBend-Solar-Project.

10. Barbose, G., et al., Tracking the Sun VII: The Installed Price of Residential and Non-Residential Photovoltaic Systems in the United States. DOE Technical Report, 2015. LBNL-188238-1.

11. GTMResearch, U.S. Residential Solar Economic Outlook 2016-2020: Grid Parity, Rate Design and Net Metering Risk. 2016.

12. $\quad$ SEPA, Photovoltaic System Price Quotes from Selected States 2014-2015. 2016.

13. Pasqualetti, M.J. and S. Haag, A solar economy in the American Southwest: Critical next steps. Energy Policy, 2011. 39: p. 887-893.

14. McRae, M., et al., PV Workforce Development and the Market for Customer-Sited PV. 2008.

15. AlabamaPower, Alabama Service Territories. http://www.alabamapower.com/aboutus/service-territory/pdf/ALServiceTerritories_Grids.pdf. 
SRNL-STI-2016-00717

Revision 0

Appendix A. Survey

\section{Alabama PV Soft Cost and Workforce Development Survey}

Savannah River

National Laboratory

The Savannah River National Laboratory (SRNL) has received funding from the Department of Energy's SunShot Initiative to help reduce PV soft costs in the Southeastern over the next three years. In order to help develop cost reduction strategies and recommendations, we must first adequately define current estimates, which are unclear for the SE US. Your assistance will help us identify your most pressing needs along with recommended solutions. Please direct questions or concerns about this survey or this project to Elise Fox at SRNL (elise.fox@srnl.doe.gov or 803-507-8560). All information provided will be kept confidential and is considered business sensitive. Thank you for your assistance with this survey.

\section{Part I. Estimation of Soft Costs}

1. What segment of the solar PV industry does your company serve? Circle all that apply.

$$
\text { Residential Commercial Utility Not Applicable }
$$

2. What is the typical size of type of installation in Alabama now?

watts-DC

Average Residential
watt-DC

Average Commercial
watt-DC Average Utility-Scale

3. What is the typical total installed cost (in dollars per watt-DC) for each segment in Alabama now?

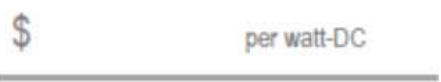

Residential

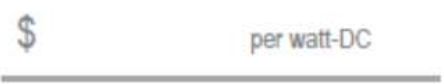

Commercial

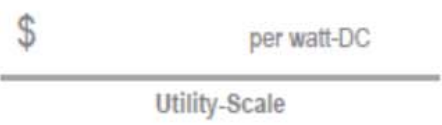

Utility-Scale

4. What percent of the typical installed cost is attributable to hardware only, now?

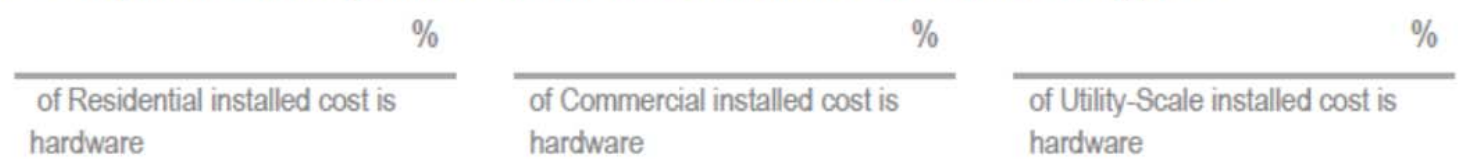

5. Of the remaining, non-hardware costs, what percent of the cost is:

\begin{tabular}{|c|c|c|c|}
\hline$\%$ & $\%$ & $\%$ & $\%$ \\
\hline $\begin{array}{l}\text { of non-hardware cost is } \\
\text { marketing, lead gen, } \\
\text { and/or sales }\end{array}$ & $\begin{array}{l}\text { of non-hardware cost is } \\
\text { permitting, inter- } \\
\text { connection (incl. fees } \\
\text { and admin. labor cost) }\end{array}$ & $\begin{array}{l}\text { of non-hardware cost is } \\
\text { installation (incl. design, } \\
\text { engineering, and } \\
\text { construction labor) }\end{array}$ & $\begin{array}{l}\text { of non-hardware cost } \\
\text { is profit, overhead, tax }\end{array}$ \\
\hline
\end{tabular}




\section{Part II. Workforce needs, workforce training needs}

1. What are your short term business needs over the next six months? Specifically, how many additional full-time hires do you expect to need in the following areas to meet business expectations over the next six months:

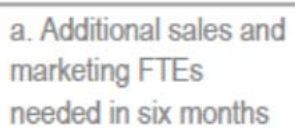

c. Additional general
business admin FTEs
needed in six months

d. Additional design, engineering FTEs needed in six months

2. What are your longer term business needs over the next three years? Specifically, how many additional full-time hires do you expect to need in the following areas to meet business expectations in 3 years:

a. Additional sales and
marketing FTEs
needed in 3 years

a. Additional sales and

needed in 3 years

b. Additional electrician
and installer FTEs
needed in 3 years

b. Additional electrician needed in 3 years

c. Additional general
business admin FTEs
needed in 3 years
d. Additional design, engineering FTEs needed in 3 years

d. Additional design,
engineering FTEs
needed in 3 years

3. If funding were available to support training of the Alabama solar workforce, what type of training would you recommend for the following positions

\begin{tabular}{|l|l|l|l|l|}
\hline & \multicolumn{3}{|c|}{ Type of certification or training you would recommend if funding were available to train } \\
your employees (check all that apply):
\end{tabular}

4. What do you see as the biggest opportunity to reduce soft costs in Alabama? Please explain. 
Part III. Tell us about your business today

1. In what Southeastern states have you focused your business so far? Circle all that apply.

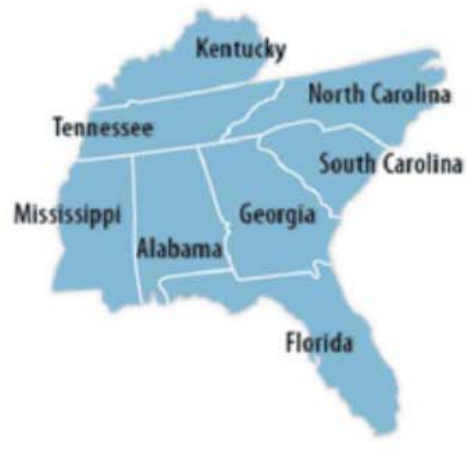

2. In what regions of Alabama have you focused your business so far? Circle all that apply.

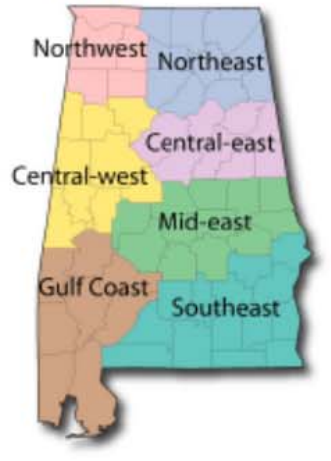

3. What is your company's business focus? What segment of the PV market do you concentrate your time on today? Please shade the areas that apply to your current business.

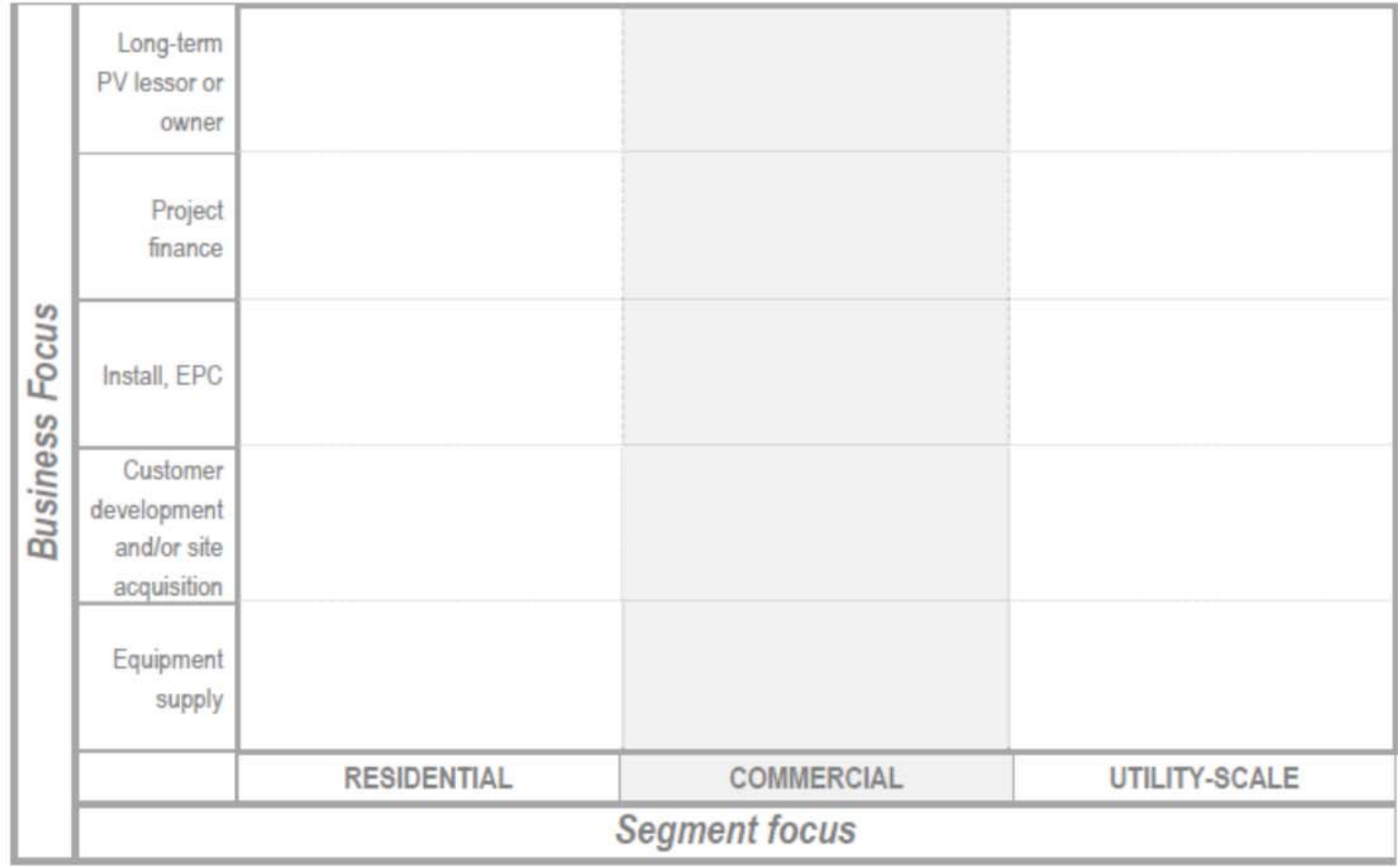

Alabama PV Soft Cost and Workforce Development SurveyPage 3 of 4 $6 / 2016$ 
SRNL-STI-2016-00717

Revision 0

4. How much solar PV capacity have you installed in your career? Circle one.
a. Not applicable, I do not install PV
b. Less than $100 \mathrm{~kW}$
c. At least $100 \mathrm{~kW}$, not more than $500 \mathrm{~kW}$
d. At least $500 \mathrm{~kW}$, not more than $2,000 \mathrm{~kW}$
e. At least $2000 \mathrm{~kW}$, not more than $5,000 \mathrm{~kW}$
f. $5,000 \mathrm{~kW}$ or more

5. How much solar PV capacity have you installed in Alabama? Circle one.
a. Not applicable; I do not install PV
b. Less than $100 \mathrm{~kW}$
c. At least $100 \mathrm{~kW}$, not more than $500 \mathrm{~kW}$
d. At least $500 \mathrm{~kW}$, not more than 2,000kW
e. At least $2000 \mathrm{~kW}$, not more than $5,000 \mathrm{~kW}$
f. $5,000 \mathrm{~kW}$ or more

6. Please provide your contact information so that we may contact you in the future. Again, all information provided will be kept confidential and is considered business sensitive. Thank you for your assistance with this survey.

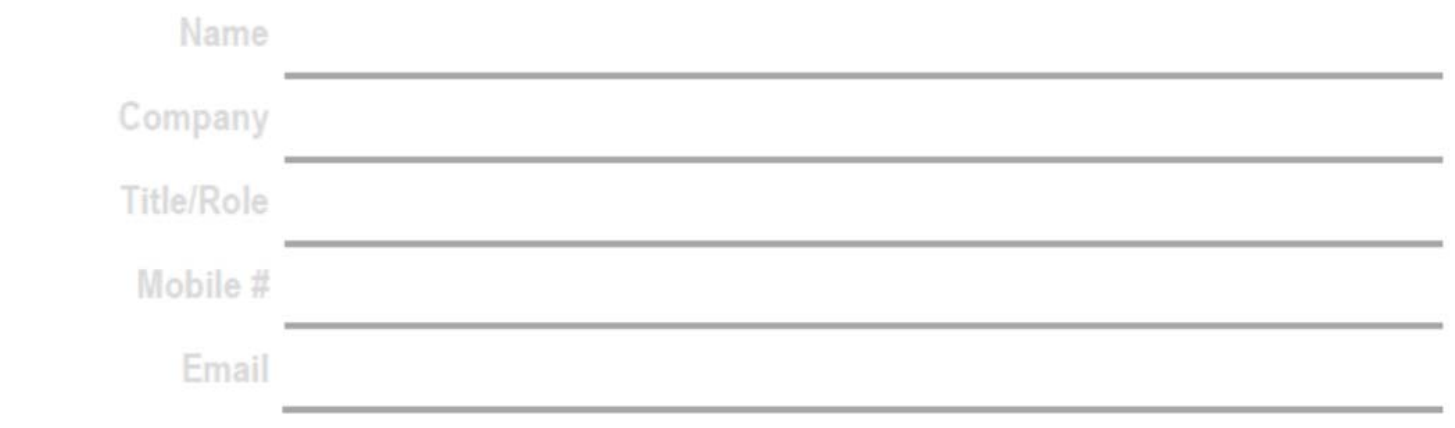

All information provided will be kept confidential and is considered business sensitive.

Thank you for your assistance with this survey. 
Appendix B. Supplemental Information

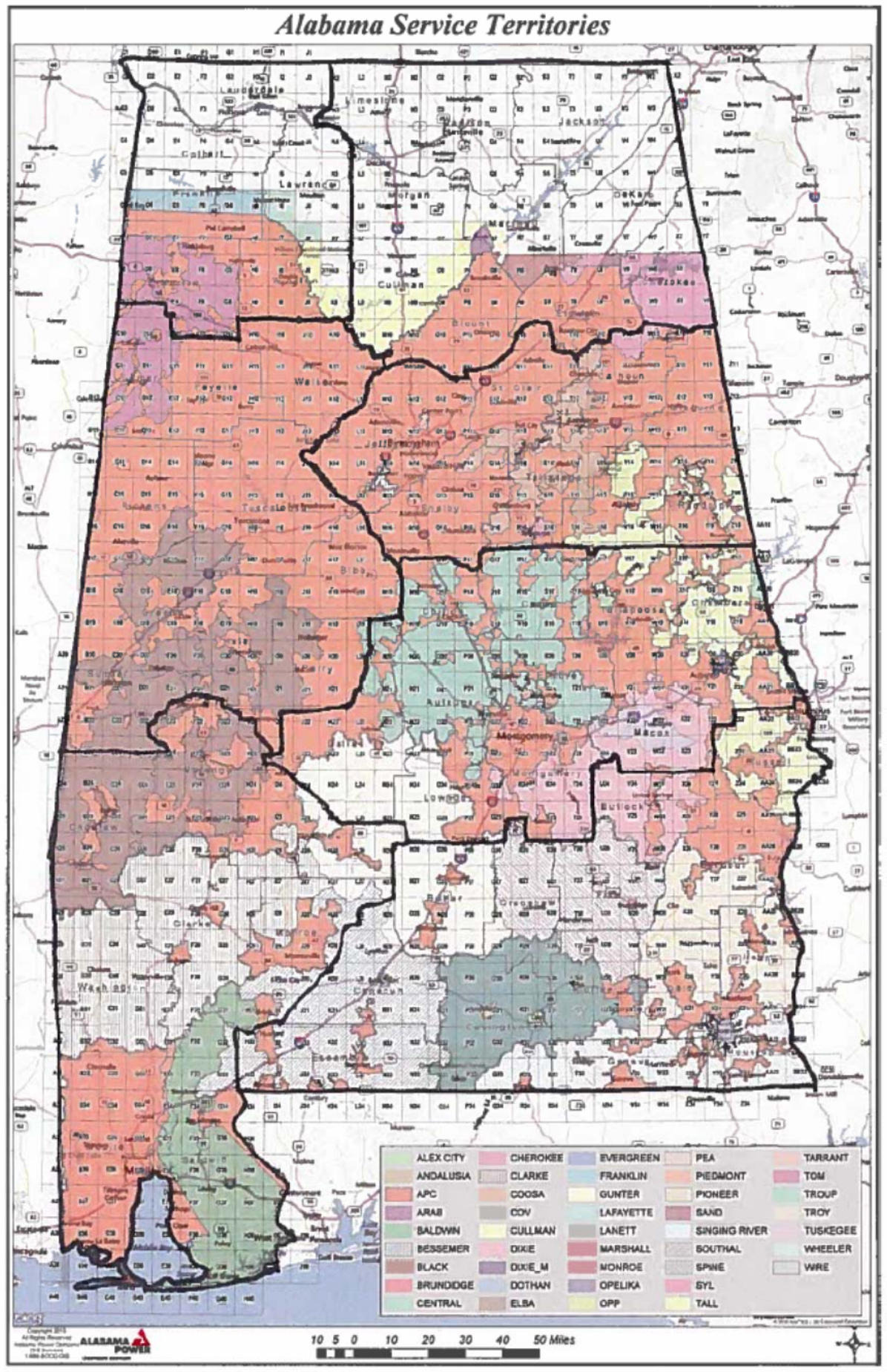

Figure B1. Power provider map with overlay of AL regions. Modified from [15] 
Table B1. Alabama Population Information by County. Data provided by the US Census Bureau

\begin{tabular}{|c|c|c|c|c|}
\hline County & Region & $\begin{array}{c}2014 \\
\text { population }\end{array}$ & median income & $\begin{array}{l}\text { persons in } \\
\text { poverty } / \%\end{array}$ \\
\hline Calhoun & $\mathrm{CE}$ & 118572 & $40,919.00$ & $20.5 \%$ \\
\hline Clay & $\mathrm{CE}$ & 13932 & $35,286.00$ & $19.5 \%$ \\
\hline Cleburne & $\mathrm{CE}$ & 14972 & $37,008.00$ & $17.0 \%$ \\
\hline Jefferson & $\mathrm{CE}$ & 658466 & $45,239.00$ & $19.5 \%$ \\
\hline Randolph & $\mathrm{CE}$ & 22913 & $36,498.00$ & $20.4 \%$ \\
\hline St. Clair & $\mathrm{CE}$ & 83593 & $51,317.00$ & $14.3 \%$ \\
\hline Shelby & $\mathrm{CE}$ & 195085 & $69,723.00$ & $9.6 \%$ \\
\hline Talladega & $\mathrm{CE}$ & 82291 & $35,896.00$ & $22.5 \%$ \\
\hline Bibb & CW & 22915 & $37,984.00$ & $18.1 \%$ \\
\hline Fayette & CW & 17241 & $33,144.00$ & $20.6 \%$ \\
\hline Greene & CW & 9045 & $22,170.00$ & $33.2 \%$ \\
\hline Hale & CW & 15760 & $30,839.00$ & $28.1 \%$ \\
\hline Lamar & CW & 14564 & $36,021.00$ & $20.6 \%$ \\
\hline Perry & CW & 10591 & $25,528.00$ & $46.9 \%$ \\
\hline \begin{tabular}{|l|} 
Pickens \\
\end{tabular} & CW & 19746 & $29,839.00$ & $25.0 \%$ \\
\hline Sumter & CW & 13763 & $22,865.00$ & $38.1 \%$ \\
\hline Tuscaloosa & CW & 194656 & $46,448.00$ & $18.0 \%$ \\
\hline Walker & CW & 67023 & $36,712.00$ & $23.5 \%$ \\
\hline Baldwin & Gulf Coast & 182265 & $50,183.00$ & $13.0 \%$ \\
\hline Choctaw & Gulf Coast & 13859 & $34,325.00$ & $25.0 \%$ \\
\hline \begin{tabular}{|l|} 
Clarke \\
\end{tabular} & Gulf Coast & 25833 & $30,951.00$ & $24.9 \%$ \\
\hline Monroe & Gulf Coast & 23070 & $30,569.00$ & $25.3 \%$ \\
\hline Marengo & Gulf Coast & 21027 & $33,714.00$ & $25.6 \%$ \\
\hline Mobile & Gulf Coast & 412992 & $43,844.00$ & $19.6 \%$ \\
\hline Washington & Gulf Coast & 17581 & $44,731.00$ & $18.5 \%$ \\
\hline \begin{tabular}{|l|} 
Wilcox \\
\end{tabular} & Gulf Coast & 11670 & $23,406.00$ & $33.7 \%$ \\
\hline Autauga & $\mathrm{ME}$ & 54,571 & $52,475.00$ & $13.1 \%$ \\
\hline \begin{tabular}{|l|} 
Chambers \\
\end{tabular} & ME & 34215 & $32,835.00$ & $21.3 \%$ \\
\hline \begin{tabular}{|l|} 
Chilton \\
\end{tabular} & $\mathrm{ME}$ & 43643 & $41,785.00$ & $18.1 \%$ \\
\hline Coosa & ME & 11539 & $32,340.00$ & $18.8 \%$ \\
\hline Dallas & $\mathrm{ME}$ & 43820 & $26,494.00$ & $35.2 \%$ \\
\hline \begin{tabular}{|l|} 
Elmore \\
\end{tabular} & $\mathrm{ME}$ & 79303 & $54,159.00$ & $14.4 \%$ \\
\hline Lee & ME & 140247 & $43,641.00$ & $25.2 \%$ \\
\hline Lowndes & ME & 11299 & $25,678.00$ & $31.4 \%$ \\
\hline Montgomery & $\mathrm{ME}$ & 229363 & $44,830.00$ & $22.5 \%$ \\
\hline \begin{tabular}{|l|} 
Tallapoosa \\
\end{tabular} & $\mathrm{ME}$ & 41616 & $38,644.00$ & $21.3 \%$ \\
\hline Macon & MR & 21452 & $30,254.00$ & $32.1 \%$ \\
\hline \begin{tabular}{|l} 
Blount \\
\end{tabular} & $\mathrm{NE}$ & 57322 & $44,409.00$ & $17.5 \%$ \\
\hline \begin{tabular}{|l|} 
Cherokee \\
\end{tabular} & $\mathrm{NE}$ & 25989 & $34,983.00$ & $18.6 \%$ \\
\hline Cullman & $\mathrm{NE}$ & 80406 & $39,415.00$ & $17.2 \%$ \\
\hline DeKalb & $\mathrm{NE}$ & 71109 & $37,977.00$ & $24.0 \%$ \\
\hline Etowah & $\mathrm{NE}$ & 104430 & $38,467.00$ & $19.0 \%$ \\
\hline \begin{tabular}{|l|} 
Jackson \\
\end{tabular} & $\mathrm{NE}$ & 53227 & $36,874.00$ & $22.0 \%$ \\
\hline Limestone & $\mathrm{NE}$ & 82782 & $49,461.00$ & $13.6 \%$ \\
\hline Madison & $\mathrm{NE}$ & 334811 & $58,203.00$ & $14.2 \%$ \\
\hline Marshall & $\mathrm{NE}$ & 93019 & $39,473.00$ & $22.0 \%$ \\
\hline Morgan & $\mathrm{NE}$ & 119490 & $45,341.00$ & $15.0 \%$ \\
\hline Colbert & NW & 54428 & $39,914.00$ & $16.7 \%$ \\
\hline Franklin & NW & 31704 & $35,450.00$ & $23.1 \%$ \\
\hline \begin{tabular}{|l|} 
Lauderdale \\
\end{tabular} & NW & 92709 & $42,703.00$ & $18.7 \%$ \\
\hline Lawrence & NW & 34339 & $40,356.00$ & $16.6 \%$ \\
\hline Marion & NW & 30776 & $33,819.00$ & $20.2 \%$ \\
\hline Winston & NW & 24484 & $34,064.00$ & $20.1 \%$ \\
\hline Barbour & SE & 27457 & $35,634.00$ & $25.4 \%$ \\
\hline Bullock & SE & 10914 & $34,804.00$ & $35.1 \%$ \\
\hline Butler & SE & 20947 & $31,571.00$ & $25.0 \%$ \\
\hline \begin{tabular}{|l} 
Coffee \\
\end{tabular} & SE & 49948 & $45,558.00$ & $16.8 \%$ \\
\hline Conecuh & SE & 13228 & $24,433.00$ & $30.6 \%$ \\
\hline
\end{tabular}


Appendix B (continued)

\begin{tabular}{|l|l|r|rr|r|}
\hline \multicolumn{1}{|c|}{ County } & \multicolumn{1}{|c|}{ Region } & $\begin{array}{c}\text { 2014 } \\
\text { population }\end{array}$ & \multicolumn{1}{c|}{ median income } & $\begin{array}{c}\text { persons in } \\
\text { poverty/\% }\end{array}$ \\
\hline Covington & SE & 37765 & $\$$ & $39,256.00$ & $20.8 \%$ \\
\hline Crenshaw & SE & 13906 & $\$$ & $37,349.00$ & $21.2 \%$ \\
\hline Dale & SE & 50251 & $\$$ & $44,473.00$ & $22.4 \%$ \\
\hline Escambia & SE & 38319 & $\$$ & $44,883.00$ & $15.3 \%$ \\
\hline Geneva & SE & 26790 & $\$$ & $36,268.00$ & $23.9 \%$ \\
\hline Henry & SE & 17302 & $\$$ & $42,926.00$ & $17.3 \%$ \\
\hline Houston & SE & 101547 & $\$$ & $41,077.00$ & $20.1 \%$ \\
\hline Pike & SE & 32899 & $\$$ & $32,798.00$ & $26.4 \%$ \\
\hline Russell & SE & 52947 & $\$$ & $36,066.00$ & $20.9 \%$ \\
\hline Alabama & & 4780127 & $\$$ & $43,511.00$ & $18.5 \%$ \\
\hline
\end{tabular}


Revision 0

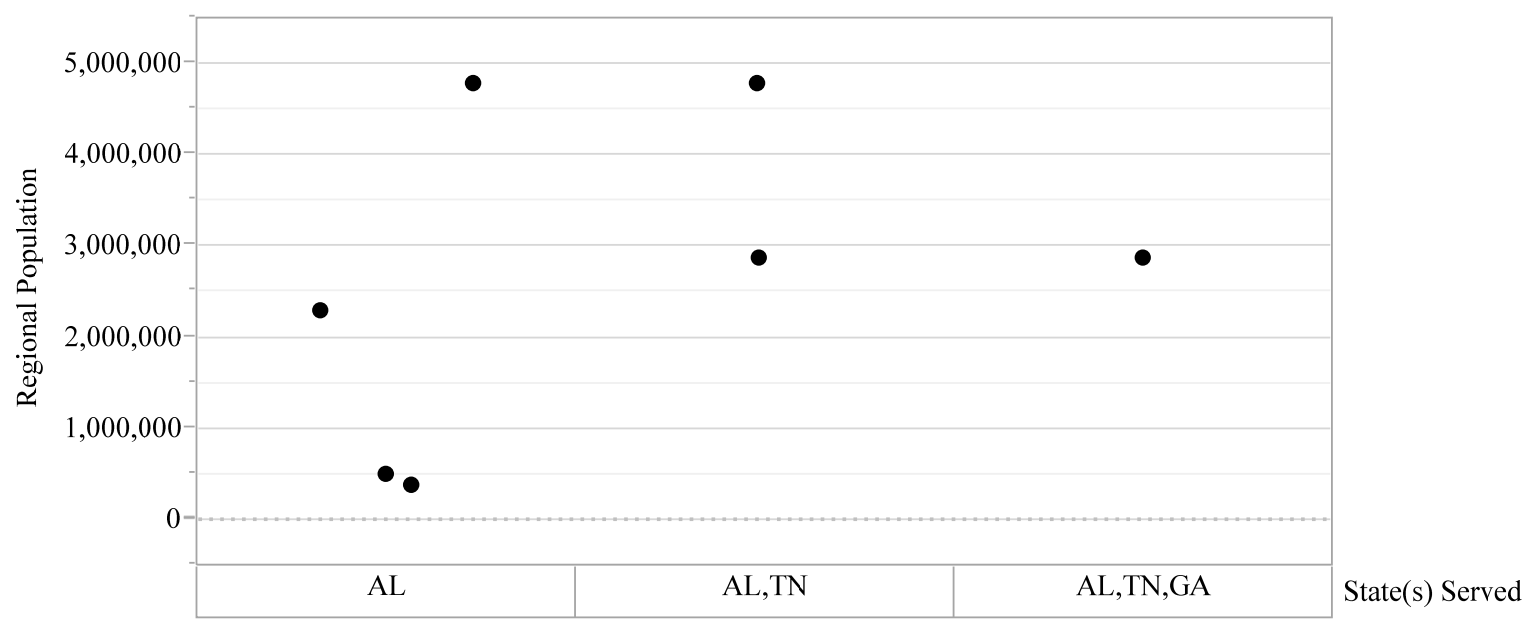

Figure B2. States served versus total population in AL served. 